\title{
Editorial Team of JIP
}

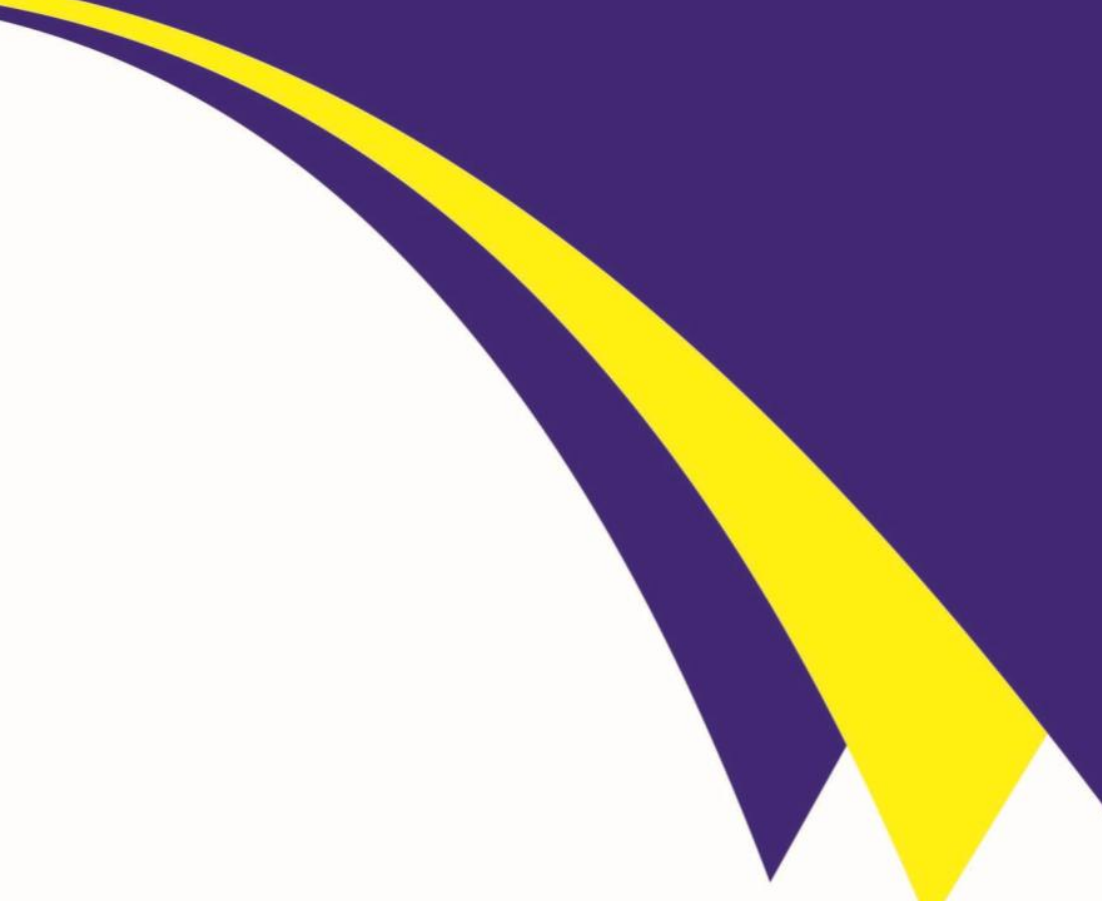

How to Get Your

Research Published...

...and then Noticed

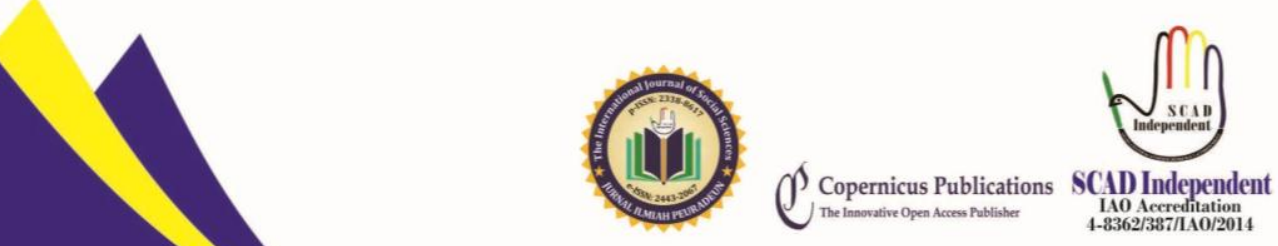


Bagaimana Membuat

Penelitian Anda di Publikasikan

Kemudian di Kutip

Disusun Oleh:

Tim Editor Jurnal IImiah Peuradeun 
Tim Penyusun:

Ramzi Murziqin

Tabrani. ZA

Syahril

Zulfadli

Amrullah

Saifullah Idris

Kamaruzzaman Bustamam-Ahmad

Habiburrahim

Miftachul Huda

Mohd Zailani Mohd Yusoff

Peter Jon Loyola Mendoza

Romi Siswanto

Fikri Sulaiman Ismail

Wang Yean Sung

Ade Ihsan Kamil

Istiqamatunnisak

Fauza Andriyadi

Editor:

Hijjatul Qamariyah

Desain dan Layout:

Irman Siswanto 
National Library: Catalog in Issue (KDT)

\title{
How to Get Your Research Published and Then Noticed
}

Editorial Team of Jurnal Ilmiah Peuradeun

ISBN: 978-602-71453-1-3

\author{
Published by: \\ SCAD Independent \\ St. Utama Rukoh, No. 3-A Rukoh, Syiah Kuala \\ Banda Aceh, Aceh-Indonesia \\ Pos Code: 23111 \\ Phone: 0811-6818656/081360562066 \\ E-mail: info@scadindependent.org \\ Website: www.scadindependent.org \\ Editor: Hijjatul Qamariyah \\ Desain \& Layout: Irman Siswanto \\ In Two Languages, English and Bahasa
}

First Printing: April 2019

ISBN: 978-602-71453-1-3

All rights reserved.

Reproduction of this paper is prohibited in the form and in any way without written permission from the publisher. 
Law of the Republic of Indonesia Number 19 of 2002 concerning Copyright

\section{Copyright Scope}

\section{Article 2:}

1. Copyright is an exclusive right for the Creator or Copyright Holder to announce or reproduce his creation, which arises automatically after a work has been created without reducing restrictions according to applicable laws and regulations.

\section{Criminal Provisions}

\section{Article 72:}

1. Anyone who intentionally or without the right to do per-art as referred to in Article 2 paragraph (1) or Article 49 paragraph (1) and paragraph (2) shall be sentenced to imprisonment of at least 1 (one) month and / or fine at least Rp. 1,000,000.00 (one million rupiah), or a maximum imprisonment of 7 (seven) years and / or a fine of at most Rp. 5,000,000,000.00 (five billion rupiah).

2. Anyone who intentionally broadcasts, exhibits, circulates, or sells to the public of a Work or goods resulting from a Copyright infringement or Related Rights as referred to in paragraph (1) shall be sentenced to a maximum of 5 years imprisonment and / or a maximum fine of Rp. 000.00 (five hundred million rupiah). 


\title{
Kata Pengantar
}

\author{
Bismillahirahmanirrahim
}

Puji dan Syukur kepada Allah SWT sepantasnya dihaturkan untuk mengawali kata pengantar buku ini serta shawalat dan salam turut tercurahkan keharibaan Nabi Muhammad SAW serta sahabat beliau sekalian.

Para pembaca yang budiman, menulis hakikatnya adalah merangkai ide dengan bantuan kata, kalimat, dan paragraf. Kata, kalimat, dan paragraf merupakan "wadah" untuk menyampaikan ide. Ide-ide itu terangkai dalam proposisi-proposisi yang kemudian diungkapkan dengan kalimat dan paragraf-paragraf. Pada saat yang sama, kita mengenal fakta, konsep, prinsip, dan prosedur. Hasil pemikiran dan atau kajian selanjutnya dituangkan dalam bentuk naskah, laporan penelitian, artikel atau wujud karya ilmiah yang lain. Karya ilmiah merupakan sebuah tulisan yang terdiri dari permasalahan dan disajikan dengan metode-metode ilmiah yang sesuai dengan kaidah penulisan karya tulis ilmiah tertentu. karya tulis ilmiah berisi data dan fakta maupun hasil penelitian seseorang yang ditulis secara runut dan sistematis.

Namun kata kuncinya adalah pencapaian tertinggi dalam sebuah karya tulis ilmiah akan dibuktikan ketika naskah tersebut telah dapat dipublikasikan. Salah satu bentuk publikasi ilmiah adalah jurnal. Tidak semua artikel hasil penelitian dapat 
dikatakan sebagai jurnal ilmiah. Sebelum melakukan penulisan artikel pada jurnal ilmiah biasanya akan melakukan telaah pustaka terkait dengan teori dan penelitian terdahulu sesuai dengan bidang keilmuan yang menjadi masalah penelitian.

Argumentasi diatas merupakan dasar pijakan tim penyusun untuk menerbitan buku How to Get Your Research Published and Then Noticed dengan maksud untuk membantu para pembaca dalam meningkatkan kemampuan melakukan penelitian ilmiah dan menuntun pembaca untuk dapat mempublikasikan karya tulis ilmiah.

Buku ini disusun secara ringkas dalam bentuk modul, karenanya konten buku ini menyajikan uraian yang lebih bersifat praktis dan diharapkan bisa digunakan sebagai bahan pengayaan diri. Dalam mempelajarinya pembaca disarankan untuk memahami terlebih dahulu esensi dari menulis karya tulis ilmiah, kemudian membaca tahapan penulisan artikel ilmiah, kandungan karya ilmiah, aspek penting dalam artikel ilmiah, dan bagaimana membuat Penelitian anda diterbitkan dan kemudian dikutip secara sistematis.

Selain itu, dalam bahasan buku ini penulis juga menyajikan sekilas kepada pembaca tentang Jurnal Ilmiah Peuradeun (JIP), The International Journal of Social Science, adalah jurnal International Open Access dan jurnal peer-review terkemuka dengan maksud untuk memperkenalkan dan mendekatkan pembaca kepada sebuah jurnal terakreditasi berdasarkan SK Dirjen PRP RistekDikti No. 48a/KPT/2017 dan saat ini terindeks di MAS, Indeks Copernicus International, Crossref, Google Cendekia, OAJI, BASE, DAIJ, ROAD, Mendeley, IOS, 
GIF, IPI, Sinta, Garuda, OAI-PMH, ROOT Indexing, CiteFactor, ResearchBible, ResearchGate, I2OR, dan lainnya. Selengkapnya dapat dibaca pada bahasan khusus tentang Jurnal IImiah Peuradeun (JIP).

Dalam penulisan buku ini kami merasa telah menerima sejumlah kontribusi pemikiran dan dorongan dari berbagai pihak. Untuk itu, pada kesempatan ini saya ingin menyampaikan terima kasih dan penghargaan kepada editorial tim Jurnal Ilmiah Peuradeun atas dedikasi dan kerja keras yang telah diwujudkan hingga selesainya penulisan naskah buku How to Get Your Research Published and Then Noticed ini.

Semoga buku panduan ini bermanfaat bagi kita semua dalam rangka mewujudkan karya tulis ilmiah yang berkualitas serta memenuhi kriteria standar internasional.

Banda Aceh, 25 Maret 2019

Editor in Chief 
How to Get Your Research Published and Then Noticed 


\section{DAFTAR ISI}

Kata Pengantar .............................................................................. iii

Daftar Isi................................................................................ vii

Menulis Artikel IImiah

Esensi Penulisan .................................................................................. 1

Tahap Penulisan Artikel IImiah ...................................................... 3

Kandungan Karya Ilmiah ................................................................... 4

Aspek Penting dalam Artikel Ilmiah ............................................. 5

Tentang Jurnal Ilmiah Peuradeun ............................................... 9

Bagaimana Membuat Penelitian anda diterbitkan, Kemudian Dikutip

Overview

Menemukan Jurnal yang Tepat.................................................... 14

Opsi Akses Terbuka ................................................................... 15

Tujuan, Fokus, dan Lingkup JIP ................................................. 17

Tujuan JIP ................................................................................. 17

Fokus dan Lingkup JIP ................................................................ 18

Tujuan Utama JIP ......................................................................... 18

Pernyataan Etika Publikasi dan Malpraktek ............................... 19

Tugas Editor.............................................................................. 21

Tugas Peninjau ......................................................................... 22

Tugas Penulis ............................................................................ 23

Siapkan Naskah Anda

Naskah Anda .................................................................................. 27

Kualitas Bahasa........................................................................... 32

Ilustrasi ................................................................................... 33

Menambahkan Data Penelitian...................................................... 33

Pernyataan Privasi ........................................................................... $\quad 34$

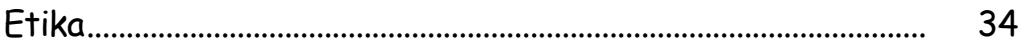

Jurnal Ilmiah Peuradeun $\{$ vii 
Kirim dan Perbaiki Naskah Anda

Bagaimana cara mengirim Naskah? ............................................. 37

Alur Kerja Editor ............................................................................ 40

Peer Review ................................................................................... 44

Prinsip Penerbitan ........................................................................... 47

Tanggung Jawab Penerbit........................................................... 48

Setelah Penerimaan: Artikel dalam Pers, Pemeriksaan, Hak Cipta, dan Lisensi

Selamat! Artikel Anda telah diterima! ......................................... 51

Artikel dalam Pers .................................................................... 51

Bukti .............................................................................................. 51

Hak Cipta dan Lisensi .................................................................. 52

Informasi Hak Cipta................................................................... 54

Lisensi Pengguna Akhir ................................................................. 55

Pernyataan Privasi ........................................................................... $\quad 57$

Promosikan Pekerjaan Anda ....................................................... 58

Pedoman Penulisan JIP .................................................................... 59

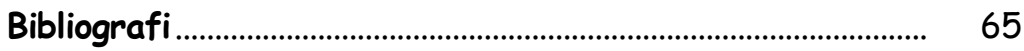




\section{Menulis Artikel IImiah}

\section{ESENSI MENULIS}

Pencapaian tertinggi dalam sebuah karya ilmiah adalah ketika dipublikasikan. Dengan publikasi jurnal ilmiah tidak hanya sebagai prasyarat akreditasi dan angka kredit melainkan juga memperkaya literasi keilmuan yang ada. Meskipun demikian dalam publikasi sebuah karya ilmiah terdapat beberapa etika yang perlu diperhatikan. Salah satu bentuk publikasi ilmiah adalah jurnal. Tidak semua artikel hasil penelitian dapat dikatakan sebagai jurnal ilmiah. Sebelum melakukan penulisan artikel pada jurnal ilmiah biasanya akan melakukan telaah pustaka terkait dengan teori dan penelitian terdahulu sesuai dengan bidang keilmuan yang menjadi masalah penelitian.

Menulis hakikatnya merangkai ide dengan bantuan kata, kalimat, dan paragraf. Kata, kalimat, dan paragraf merupakan "wadah" untuk menyampaikan ide. Ide-ide itu terangkai dalam proposisi-proposisi yang kemudian diungkapkan dengan kalimat dan paragraf-paragraf. Pada saat yang sama, kita mengenal fakta, konsep, prinsip, dan prosedur. Hasil pemikiran dan atau kajian selanjutnya dituangkan dalam bentuk naskah, laporan penelitian, artikel atau wujud karya ilmiah yang lain.

Ada tujuh hal penting agar dapat menghasilkan tulisan yang bermutu. Bermutu artinya karyanya berkualitas baik, yaitu 
isinya benar, akurat, cermat, rinci, mendalam atau analisisnya tajam, mudah dipahami/diikuti oleh alur berpikirnya, terbebas dari plagiasi.

Tulisan benar artinya benar menurut hukum agama dan landasan keilmuan masing-masing. Akurat, artinya, data yang disajikan atau hasil penelitian yang dikutip atau gagasan yang dikemukakan dapat dipertanggungjawabkan. Cermat, artinya, teliti yakni tidak ada yang kurang atau berlebih atau tidak ada yang salah tempat atau salah kutip halaman sekalipun. Rinci, artinya setiap bagian atau aspek yang disuguhkan dijabarkan ke dalam bagian-bagian yang lebih kecil sesuai dengan cakupan atau rinciannya masing-masing.

Selanjutnya, jabaran yang rinci tersebut masing-masing dijelaskan secara mendalam melalui analisis yang tajam. Berikutnya, mudah diikuti. Agar mudah diikuti, sajian ditata dalam urutan yang logis, dari yang sulit menuju mudah, dari jauh menuju dekat, dari sederhana menuju kompleks, dari global atau garis besar menuju rinci, dari lampau menuju kini atau sebaliknya dari kini menuju lampau. Uraian disajikan dengan menggunakan pilihan kata yang dipahami oleh calon pembaca, menggunakan kalimat yang jelas subjek predikatnya, dan menggunakan paragraf yang jelas ide pokoknya.

Terakhir, tulisan harus terbebas dari plagiasi. Artinya, bila mengutip pendapat orang lain, atau data orang lain atau data lembaga, atau temuan orang lain, wajib dilakukan secara hati-hati dan cermat dengan memperhatikan cara-cara pengutipan dan perujukan sesuai dengan ketentuan yang berlaku sehingga tidak terjerumus ke perilaku plagiasi, baik disengaja maupun tidak. 
Artikel untuk jurnal ilmiah dibedakan menjadi dua jenis, yakni artikel hasil penelitian dan artikel gagasan konseptual (artikel review). Kedua jenis artikel itu mempunyai bahan dan komponen yang berbeda. Artikel hasil penelitian, bahan dasarnya adalah laporan (sebuah) penelitian. Bertolak dari laporan penelitian, penulis artikel mengolah laporan penelitian itu menjadi artikel hasil penelitian. Sementara itu, artikel gagasan konseptual bahannya adalah gagasan atau pemikiran penulis. Gagasan atau pemikiran penulis selanjutnya dipadukan dengan gagasan-gagasan para penulis atau ahli sebelumnya. Bisa juga dipadukan dengan hasil-hasil penelitian sebelumnya.

\section{TAHAPAN PENULISAN ARTIKEL ILMIAH}

PRAMENULIS. Produk puncak pramenulis adalah terwujudnya kerangka tulisan atau kerangka karangan. Untuk menghasilkan kerangka tulisan penulis (1) membaca berbagai sumber (buku, laporan penelitian, jurnal, majalah, dan sumber-sumber lainnya baik tercetak maupun yang tersaji secara online), yang dapat disertai kegiatan pengutipan dan membuat kutipan tematik atau anotasi bibliografi tematik, (2) merenung/berpikir (berdiskusi dalam diri sendiri), (3) berdiskusi (berpikir dengan orang lain), melakukan pengamatan yang dapat disertai kegiatan pencatatan, dan (5) melakukan kegiatan lainnya yang bermanfaat untuk menghasilkan kerangka tulisan. Urutan kelima kegiatan itu tidak prosedural. Artinya, dapat dimulai dari mana saja. Mungkin diawali dari pengamatan dilanjutkan membaca sumber atau berdiskusi dulu dan setelah itu membaca sumber dan melakukan pengamatan. Dari proses itu akhirnya akan dihasilkan kerangka tulisan yang baik, yakni 
sistematis (urutannya), rinci (jabarannya), lengkap (informasinya), dan mendalam (analisis/kajiannya).

\section{KANDUNGAN KARYA ILMIAH}

Terdapat beberapa unsur atau kandungan karya ilmiah (naskah, laporan penelitian, artikel, buku, atau bentuk lainnya), yang terdiri atas 9 unsur berikut.

1. Gagasan dan/atau klaim penulis. Gagasan ilmiah berupa pernyataan ilmiah penulis mengenai suatu hal atau masalah atau konsep atau prosedur atau teori tertentu yang dijelaskan lebih lanjut dengan menggunakan contoh atau ilustrasi atau rincian atau bukti tertentu. Gagasan ilmiah ini sangat penting karena merupakan unsur yang dapat membedakan dengan tulisan orang lain. Orisinalitas tulisan juga akan muncul melalui gagasan ini.

2. Fakta (sekumpulan kejadian atau peristiwa nyata yang terkait dengan hal/entitas tertentu yang sedang dijelaskan oleh penulis. Fakta bersifat sporadis.

3. Data penelitian (fakta yang tersusun sistematis, dikumpulkan dengan instrumen tertentu untuk tujuan penelitian tertentu). Data bersifat sistematis.

4. Pandangan-pandangan ahli sebelumnya (pemikiran-pemikiran atau gagasan ahli di bidangnya, baik yang telah teruji maupun belum, mengenai suatu hal atau masalah atau konsep atau prosedur atau teori tertentu.

5. Hasil-hasil penelitian (data penelitian yang telah dianalisis dengan teknik tertentu untuk menjawab rumusan masalah yg telah ditetapkan).

6. Teori-teori yang relevan, termasuk konsep-konsep dan prosedur yang relevan (penjelasan sistematis yg komprehensif 
dan tuntas ttg suatu hal/fenomena/entitas oleh pakar di bidangnya berdasarkan penelitian dan/atau gagasan-gagasan ilmiahnya). 1-6 termasuk unsur isi.

7. Penalaran, merujuk kepada bagaimana isi KI itu diuraikan atau dijabarkan, dihubung-hubungkan, dan disusun dalam jalinan yang padu dan sistematis. Tulisan yang baik berawal dari organisasi gagasan yang baik. Organisasi gagasan itu terbangun melalui penalaran penulisnya.

8. Bahasa, mencakup pilihan dan bentukan kata, kalimat, paragraf, dan penggunaan ejaan/tanda baca secara cermat.

9. Tampilan visual, dapat berupa gambar, grafik, bagan, atau lainnya.

\section{ASPEK PENTING DALAM ARTIKEL ILMIAH}

1. Baru, yakni substansi (perihalnya) atau sudut pandang/metode yang digunakan. Tulisan tidak hanya mengemukakan kembali. Untuk itu, penulis harus berani berpikir beda bahkan kalau perlu melawan arus. Bila substansi sudah ditetapkan, langkah selanjutnya adalah mengumpulkan bahan-bahan (pandangan ahli, hasil penelitian, teori, hasil observasi, dll.) dari berbagai sumber (buku referensi, jurnal, laporan penelitian, naskah). Apabila substansi kurang baru atau bahkan sudah banyak dibahas orang, pilihlah sudut pandang yang baru. Termasuk sudut pandang adalah metode yang digunakan.

Sebelum mengemukakan gagasan baru, kita wajib menelusuri atau melacak gagasan-gagasan "lama" yang telah dikemukakan sebelumnya. Setelah berhasil menemukan gagasan-gagasan "lama" itulah, penulis berikutnya akan lebih 
mudah mengemukakan pemikirannya yang berbeda atau baru bila dibandingkan dengan gagasan-gagasan "lama" tersebut. Tanpa didahului dengan menemukan gagasan "lama", penulis berikutnya bisa "tertipu" karena dikiranya gagasan yang dikemukakan itu baru, ternyata sudah banyak ditulis atau dikemukakan orang lain atau penulis-penulis sebelumnya. Di sinilah perlunya setiap peneliti/penulis menelusuri gagasangagasan peneliti/penulis terdahulu.

Berikut beberapa contoh gagasan "lama" yang telah dikemukakan para peneliti/penulis terdahulu seputar bagaimana mengajarkan atau lebih tepatnya membelajarkan siswa untuk berpikir di sekolah. (1) Eggen and Kauchak (2001) believe the best approach to teach for thinking occurs when it is taught explicitly and within the context of the regular curriculum (Lang dan Evans, 2006: 443), dalam buku yang berjudul Models, Strategies, and Methods for Effective Teaching. ....(2) These results provide robust evidence that explicit instruction is an effective method for teaching critical thinking skills to high school students. Dikutip dari artikel berjudul Pedagogy for developing critical thinking in adolescents: Explicit instruction produces greatest gains, karya Lisa $M$. Marina, Diane F. Halpernb, dalam jurnal Thinking Skills and Creativity, halaman 1-13, tahun 2011. (3) Critical thinking is a learnable skill; the instructor and peers are resources in developing ciitical thinking skills'. Padangan ini dikemukakan oleh John C. Bean, dalam buku Engaging Ideas, 2001.

Itu berarti, apabila penulis berikutnya akan menawarkan gagasan baru seputar pembelajaran berpikir wajib 
menjelaskan terlebih dahulu gagasan-gagasan "lama" di atas. Setelah itu, barulah dikemukakan gagasan baru yang ditawarkan. Dengan demikian, akan tampak jelas di mana letak kebaruan dan keunggulan gagasan yang kita tawarkan.

2. Benar, yakni benar menurut kaidah keilmuan masing-masing, didukung data dan hasil penelitian atau setidaknya pandangan ahli. Bagaimana kalau perihalnya baru/belum banyak dibahas para ahli? Dalam filsafat ilmu, kita mengenal teori kebenaran, yakni teori korespondensi, koherensi, dan pragmatik. Menurut pandangan koherensi, sesuatu benar bila pemikiran kita koheren atau tidak bertentangan atau koheren dengan teori yang sudah ada. Bagaimana bila pemikiran kita yang baru melawan arus?

3. Mendalam, cara pembahasannya. Dengan pembahasan yang mendalam, dimensi yang dipentingkan adalah dimensi vertikal, bukan horizontal. Bagaimana pembahasan yang mendalam itu? Pembahasan yang tidak hanya pada kulit-kulit atau permukaannya, misalnya, bukan hanya definisi atau ciri-ciri. Akan tetapi sampai pada kandungan isi yang paling dalam, hubungan-hubungannya, dan perbedaan-persamaannya.

4. Tuntas, yakni tidak ada yang tersisa. Aspek-aspek yang terkait dibahas semuanya, tidak ada yang tersisa. Bagaimana kalau ada pembatasan jumlah halaman, misalnya? Dalam konteks ini, perlu penjelasan ruang lingkup atau pembatasan masalah. Yang telah ditetapkan sebagai ruang lingkup itulah yang wajib dibahas secara tuntas. Selain mencakup semua aspek, pembahasan yang tuntas juga mendalam. 
5. Bermanfaat, bagi pengembangan ilmu dan kehidupan praktis. Tulisan ilmiah wajib memenuhi kedua manfaat itu. Tulisan ilmiah bermula dari praktik kehidupan nyata yang diteorikan (induktif) atau dari teori yang dipraktikkan (deduktif) kemudian dituliskan atau mondar-mandir dari teori ke praktik, dari praktik ke teori. Teori baru membenahi teori lama berdasarkan temuan baru dalam praktik. Untuk kehidupan praktis, perihal yang dibahas diarahkan untuk memecahkan masalah yang terjadi di tengah masyarakat.

6. Terhindar dari Plagiasi, sekecil apa pun. Di atas segalanya, tulisan ilmiah wajib terhindari dari plagiasi, apa pun wujudnya, baik disengaja maupun tidak disengaja, baik plagiasi dari karya orang lain maupun dari karya sendiri (autoplagiasi). Lebih baik, tulisan itu sederhana akan tetapi asli karya sendiri, daripada analisisnya canggih atau kompleks tetapi hasil plagiasi. Agar terhindar dari plagiasi, utamakan gagasan baru milik sendiri. Gagasan baru yang dikemukakan harus kuat atau menonjol, sementara gagasan orang lain cukup sebagai pendukung atau pelengkapnya. Dengan cara ini, plagiasi dapat dihindari.

Dari penjelasan di atas, unsur atau kandungan karya ilmiah merujuk pada kandungan substantif isi yang ada dalam karya ilmiah, sementara itu komponen karya ilmiah merujuk pada kandungan komponensial yang berkaitan dengan kerangka sistematik. Unsur karya ilmiah ada dalam setiap kalimat dan paragraf. Selanjutnya, kalimat dan paragraf tersebut ada dalam setiap komponen karya ilmiah. 


\section{Tentang Jurnal IImiah Peuradeun}

Jurnal IImiah Peuradeun (JIP), The International Journal of Social Science, adalah jurnal International Open Access dan jurnal peer-review terkemuka. JIP berspesialisasi dalam Ilmu Sosial, mengkonsolidasikan kegiatan penelitian mendasar dan terapan dengan cakupan yang sangat luas. JIP diterbitkan oleh SCAD Independent, yang terbit 3 kali per tahun (Januari, Mei, dan September) dan diterbitkan secara online pada akhir bulan edisi. Semua artikel yang diterbitkan tersedia secara online dan cetak. Artikel-artikel ini menjalani proses peer-review double-blind yang ketat. JIP akan menerbitkan naskah yang belum pernah dipublikasikan dalam publikasi apa pun atau tidak ada publikasi yang diminta atau dipertimbangkan oleh media lain, sesuai dengan pernyataan etika pada JIP. JIP adalah jurnal Open Access di media cetak dan online. JIP menerbitkan ide-ide inti dari artikel atau hasil penelitian dari ilmu sosial, yang memiliki dampak signifikan dan kontribusi nyata bagi masyarakat di dunia yang luas, praktis dan akademis. Ini termasuk studi dan tinjauan yang dilakukan oleh tim multidisiplin serta penelitian yang mengevaluasi atau melaporkan hasil atau pelaksanaan tim atau proses ilmiah tersebut secara umum.

JIP telah diterbitkan sejak 2013, sesuai dengan SK PDII-LIPI dengan p-ISSN: 2338-8617 dan e-ISSN: 2443-2067, dan berspesialisasi dalam Ilmu Sosial, seperti; Politik, Hukum, Pendidikan, 
Agama, Budaya dan Humaniora. JIP menerbitkan ide-ide inti dari artikel atau hasil penelitian, yang memiliki dampak signifikan dan kontribusi nyata bagi masyarakat di dunia yang luas, praktis dan akademis. Pada awal publikasi (2013), JIP diterbitkan hanya dalam versi cetak di setiap edisi. Kemudian, mulai tahun 2014, selain penerbitan di media cetak, JIP mulai dipublikasikan secara online yang terintegrasi langsung dengan platform situs web SCAD Independent. Untuk memiliki artikel yang berkualitas baik, dari 2014 hingga 2016 JIP telah diproses secara online, menggunakan sistem aplikasi sendiri melalui formulir panel penerbit, dan menggunakan email untuk korespondensi antara editor dan reviewer. Untuk meningkatkan kualitas publikasi internasional, sejak Februari 2017, JIP telah meningkatkan kinerja publikasi dengan menggunakan platform Open Journal Systems (OJS) versi 3 yang disediakan oleh PKP (Public Knowledge Project).

Jurnal IImiah Peuradeun (JIP) mengkhususkan diri dalam ilmu sosial, yang bertujuan untuk mewakili dan mempublikasikan hasil penelitian asli dan ulasan di bidang ilmu sosial yang disampaikan oleh praktisi dan peneliti, yang memiliki dampak signifikan dan kontribusi nyata kepada masyarakat luas, praktis dan dunia akademik. Ini termasuk studi dan tinjauan yang dilakukan oleh tim multidisiplin serta penelitian yang mengevaluasi atau melaporkan hasil atau pelaksanaan tim atau proses ilmiah tersebut secara umum. Jurnal Ilmiah Peuradeun (JIP) mencakup berbagai topik penelitian dalam Ilmu Sosial, seperti: pendidikan, politik, hukum, agama, budaya dan kebijakan publik, termasuk ilmu alam untuk ilmu sosial. JIP menerbitkan penelitian inovatif dan berkualitas tinggi di garis depan semua ilmu pengetahuan dengan penekanan pada penelitian 
interdisipliner. Kami terutama mendorong naskah yang terletak di antarmuka ilmu sosial. Tujuan utama JIP adalah untuk menyebarluaskan pengetahuan ilmiah dan menghasilkan debat dalam konteks interdisipliner, menghubungkan berbagai bidang ilmu sosial. Dengan demikian, kontribusi ini akan membantu pengembangan masyarakat dengan dasar ilmiah yang ketat, terbukti secara internasional. Selain itu, untuk menawarkan forum multidisiplin kepada para sarjana dan ahli dari berbagai bidang dan untuk menjembatani kesenjangan di antara mereka, di dalam dan di semua aspek ilmu.

Jurnal ini menyediakan akses terbuka langsung ke kontennya berdasarkan prinsip yang membuat penelitian tersedia secara bebas untuk umum dan mendukung pertukaran pengetahuan global yang lebih besar. JIP sebagai Jurnal Akses Terbuka dilisensikan di bawah Lisensi Internasional Creative Commons 4.0 (CC-BY-SA) atau lisensi yang setara sebagai lisensi optimal untuk publikasi, distribusi, penggunaan, dan penggunaan kembali karya ilmiah. Izin akses di luar lingkup lisensi ini mungkin tersedia di perpustakaan digital dan basis data jurnal akses terbuka.

Jurnal ini mencakup berbagai bidang yang sangat luas dan kami menerima kiriman dari para praktisi di semua tingkatan dan dari seluruh dunia. JIP menerbitkan penelitian inovatif dan berkualitas tinggi di garis depan semua ilmu pengetahuan dengan penekanan pada penelitian interdisipliner. Kami terutama mendorong naskah yang terletak di antarmuka ilmu kehidupan dan baik ilmu yang lebih kuantitatif atau ilmu sosial. Kami percaya bahwa berbagai disiplin ilmu ini semuanya dapat berkontribusi pada JIP dan memberikan wawasan orisinal untuk 
pertanyaan yang paling berulang. Artikel penelitian asli dan naskah tinjauan disambut sama baiknya.

JIP akan menerbitkan naskah yang belum pernah dipublikasikan dalam publikasi apa pun atau tidak ada publikasi yang diminta atau dipertimbangkan oleh media lain, sesuai dengan pernyataan etika pada JIP. Dan naskah yang diserahkan, ditulis dalam bahasa Inggris yang memenuhi aturan penulisan yang baik dan benar.

Jurnal Ilmiah Peuradeun telah menjadi Anggota CrossRef. Oleh karena itu, semua artikel yang diterbitkan akan memiliki nomor DOI yang unik, dan JIP juga telah diakreditasi oleh Kementerian Teknologi Riset dan Pendidikan Tinggi Republik Indonesia (SK Dirjen PRP RistekDikti No. 48a / KPT / 2017). Akreditasi ini berlaku mulai 30 Oktober 2017 hingga 30 Oktober 2022. JIP saat ini diindeks oleh MAS, Indeks Copernicus International, Crossref, Google Cendekia, OAJI, BASE, DAIJ, ROAD, Mendeley, IOS, GIF, IPI, Sinta, Garuda, OAI-PMH, ROOT Indexing, CiteFactor, ResearchBible, ResearchGate, I2OR, dan lainnya.

JIP berada di bawah naungan SCAD Independent. SCAD Independent adalah organisasi profesional ilmiah dan publikasi telah melakukan penelitian di berbagai bidang, seperti masalah sosial, pendidikan, demokrasi, politik, hukum, kebijakan publik, agama dan budaya. SCAD Independent didirikan pada tahun 2010 dengan Akta Notaris No. 01, tertanggal 29 Oktober 2012. Salah satu visinya adalah: "Menyediakan tempat bagi para intelektual untuk berkontribusi pada pembangunan Indonesia khususnya dan dunia pada umumnya ke arah yang lebih baik". Sejak 2014, SCAD Independent telah terakreditasi di International Accreditation Organization (IAO). 


\section{Bagaimana Membuat Penelitian anda diterbitkan dan Kemudian Dikutip}

\section{OVERVIEW}

Sebagai peneliti, Anda membuat langkah besar dalam memajukan pengetahuan esensial. Prestasi Anda dapat menyelamatkan hidup dan meningkatkan cara kita hidup. Jika Anda siap untuk membagikan pengetahuan Anda dengan dunia, buklet ini menguraikan peluang terbaik untuk menerbitkan penelitian Anda - dan untuk melihatnya dibagikan secara global. Pertanyaan pertama yang Anda ajukan pada diri sendiri adalah, "Apakah saya punya cerita untuk diceritakan?" Editor dan pengulas mencari penelitian asli dan inovatif yang menambah bidang studi mereka, atau segera berdampak pada perawatan pasien. Ini berarti kesimpulan Anda harus masuk akal dan didasarkan pada data yang cukup kuat.

Kedua, tanyakan pada diri sendiri, "apakah ada audiens untuk temuan penelitian saya?" Semakin riset Anda orisinal dan inovatif, semakin banyak orang akan tertarik. Pertimbangkan apakah penelitian Anda menarik bagi audiens lokal, regional atau internasional. Mengidentifikasi audiens Anda adalah faktor utama dalam memilih jurnal yang tepat untuk mengirimkan naskah Anda. Anda dapat membaca lebih lanjut tentang memilih jurnal di halaman berikutnya. 
Ada beberapa jenis artikel penelitian:

1. Surat dan komunikasi cepat atau pendek dimaksudkan untuk komunikasi cepat dan awal dari kemajuan yang signifikan atau asli, tanpa menyertakan terlalu banyak data atau detail.

2. Naskah tinjauan merangkum perkembangan terakhir pada topik tertentu, tanpa memperkenalkan data baru.

3. Artikel lengkap berisi data, detail, perkembangan, dan hasil yang signifikan.

4. Elemen-elemen penelitian memungkinkan Anda untuk mempublikasikan hasil penelitian, seperti data, perangkat lunak, metode, video, dan banyak lagi, secara singkat, artikel-artikel yang menarik.

Jika Anda tidak yakin jenis artikel yang akan ditulis, diskusikan pilihan Anda dengan penyelia atau kolega Anda. Untuk keperluan buklet ini, kami menawarkan panduan untuk menulis dan menerbitkan artikel lengkap. Setelah Anda memutuskan untuk menulis artikel lengkap, ikuti pedoman jurnal pilihan Anda, dan pedoman umum untuk penulisan ilmiah yang diuraikan di bagian berikut.

\section{MENEMUKAN JURNAL YANG TEPAT}

Menemukan jurnal yang tepat untuk artikel Anda bisa menjadi kunci untuk menjangkau audiens target Anda.

1. Mempertimbangkan jenis artikel yang ingin Anda terbitkan (panjang penuh, surat, ulasan, hasil penelitian).

2. Periksa referensi di artikel Anda, untuk memberikan indikasi kemungkinan jurnal yang menarik.

3. Baca tujuan dan ruang lingkup jurnal di beranda jurnal 
4. Baca atau unduh Panduan jurnal untuk Penulis.

5. Periksa apakah jurnal itu hanya undangan; beberapa jurnal hanya menerima artikel setelah mengundang penulis untuk mengirim.

6. Periksa kinerja jurnal untuk jadwal ulasan dan publikasi

7. Jika Anda perlu mempublikasikan akses terbuka,

8. Ingat bahwa Jurnal Ilmiah Peuradeun menjelaskan opsi akses terbuka mereka di beranda jurnal.

9. Kirimkan naskah Anda hanya ke satu jurnal sekaligus.

\section{OPSI AKSES TERBUKA}

Secara umum, akses terbuka menunjukkan akses gratis dan permanen ke penelitian yang dipublikasikan, dikombinasikan dengan pedoman yang jelas bagi pembaca untuk berbagi dan menggunakan konten. Ada dua jenis utama akses terbuka: emas dan hijau. Apa perbedaan antara akses terbuka emas dan hijau?

"Akses terbuka emas: merujuk pada karya yang segera tersedia gratis di situs publikasi untuk setiap anggota masyarakat. Pasca-Finch biasanya dianggap bahwa akses tersebut didukung oleh biaya pemrosesan artikel sisi penulis (APC) ... "(Vincent \& Wickham, 2013, hlm. 121). Secara umum, "Biaya Pemrosesan Artikel/ Penerbitan" berarti seorang penulis, setelah menerima sebuah karya, diharuskan membayar biaya publikasi. Jurnal akses terbuka "Emas Murni" tidak berbasis langganan dan hanya membebankan biaya APC sebagai sarana untuk menutup biaya (Akses Terbuka Bisnis, Inovasi, dan Keterampilan. Laporan Kelima Sesi 2013-14, 2013, hal. 3)

"Akses terbuka hijau: merujuk pada pekerjaan yang tersedia untuk umum di repositori, berbasis institusi atau subjek, setelah periode embargo. Varian akses terbuka Hijau tergantung pada apakah yang tersedia setelah periode embargo adalah teks akhir 
yang dikirimkan penulis (atau 'pra-cetak') atau artikel dalam bentuk pasca-referensi (atau 'pasca-cetak'). "( Vincent \& Wickham, 2013, hlm. 121).

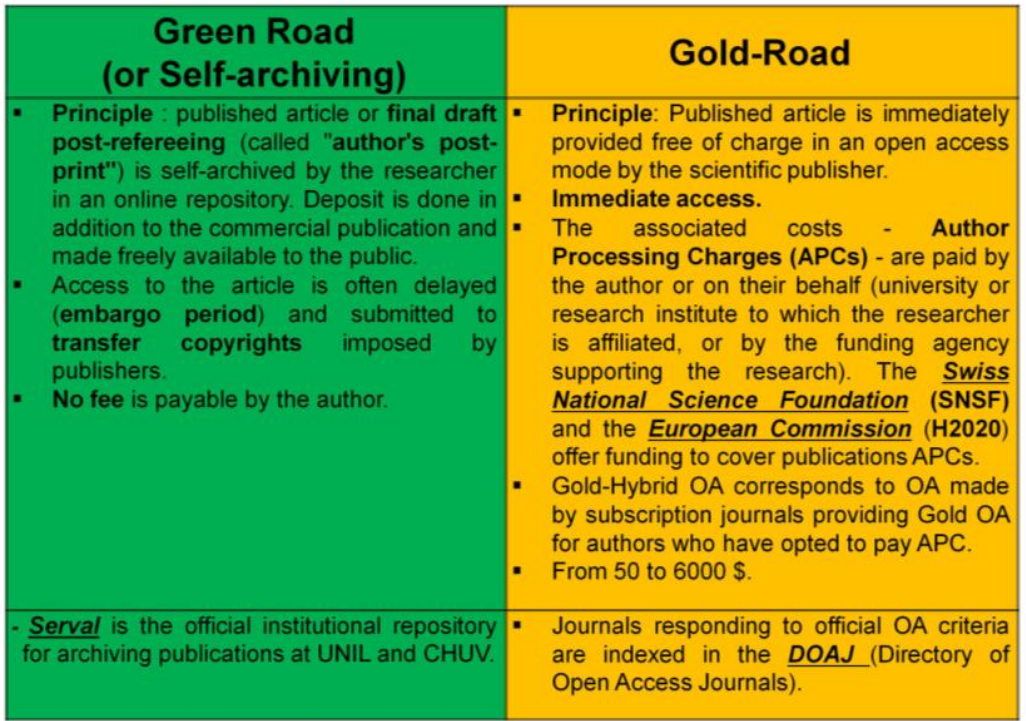

Jurnal Ilmiah Peuradeun (JIP) menyediakan akses terbuka langsung ke kontennya dengan prinsip bahwa membuat penelitian tersedia secara bebas untuk publik mendukung pertukaran pengetahuan global yang lebih besar. Pernyataan ini didasarkan pada OASPA, Inisiatif Akses Terbuka Budapest, dan Pernyataan Bethesda tentang Penerbitan Akses Terbuka. JIP sangat menghargai informasi pribadi penulisnya. Kami akan secara agresif mengejar semua jalan hukum untuk melindungi privasi penulis dan pengguna kami dari penggunaan yang tidak sah.

Semua materi yang diterbitkan oleh JIP dilindungi oleh undang-undang hak cipta dan kekayaan intelektual internasional. JIP dilisensikan di bawah Lisensi Internasional Creative 
Commons 4.0 (CC-BY-SA) atau lisensi yang setara sebagai lisensi optimal untuk publikasi, distribusi, penggunaan, dan penggunaan kembali karya ilmiah. Izin akses di luar lingkup lisensi ini mungkin tersedia di perpustakaan digital dan basis data jurnal akses terbuka.

Lisensi ini memungkinkan siapa pun untuk menulis, memperbaiki, dan membuat kreasi turunan bahkan untuk tujuan komersial, selama kredit yang sesuai dan pengakuan yang tepat terhadap publikasi asli dari jurnal dibuat untuk memungkinkan pengguna untuk melacak kembali ke naskah asli dan penulis.

\section{TUJUAN, FOKUS DAN RUANG LINGKUP}

Jurnal Ilmiah Peuradeun (JIP), adalah peer-review terkemuka dan jurnal akses terbuka, diterbitkan oleh SCAD Independent, Aceh, Indonesia dengan p-ISSN: 2338-8617 dan e-ISSN: 2443-2067, telah diakreditasi oleh Kementerian Riset Teknologi dan Pendidikan Tinggi Republik Indonesia (SK Dirjen PRP RistekDikti No. 48a / KPT / 2017). JIP diterbitkan 3 kali per tahun (Januari, Mei, dan September) dan diterbitkan secara online pada akhir bulan edisi. Semua artikel yang diterbitkan tersedia online dan Akses Terbuka.

\section{Tujuan}

Jurnal IImiah Peuradeun, adalah jurnal peer-review dan akses terbuka terkemuka, yang menerbitkan karya ilmiah, dan mengkhususkan diri dalam IImu Sosial, mengkonsolidasikan kegiatan penelitian fundamental dan terapan dengan cakupan yang sangat luas dan memiliki dampak yang signifikan dan kontribusi nyata bagi komunitas di dunia yang luas, praktis dan akademis. Ini termasuk 
studi dan tinjauan yang dilakukan oleh tim multidisiplin serta penelitian yang mengevaluasi atau melaporkan hasil atau pelaksanaan tim atau proses ilmiah tersebut secara umum. Jurnal ini berupaya untuk menarik audiensi interdisipliner dan kepenulisan yang berfokus pada penelitian dunia nyata. Ini menarik kertas dari berbagai bidang ilmu sosial dengan proses peer-review double-blind yang efisien dan berkualitas.

Tujuan utama Jurnal Ilmiah Peuradeun adalah untuk menerbitkan karya ilmiah dalam ilmu sosial yang didefinisikan dalam pengertian klasik yaitu dalam ilmu sosial, humaniora, dan ilmu alam. Penelitian yang dipublikasikan dapat mengambil model teoritis atau spekulatif serta statistik dan matematika untuk mempromosikan pemikiran interdisipliner, dan untuk menyediakan para sarjana platform untuk bertukar pengetahuan dari berbagai perspektif dan lokasi. Kontribusi diterima dari semua bidang yang memiliki komentar yang relevan dan berwawasan untuk membuat tentang ilmu sosial.

\section{Fokus dan Cakupan}

JIP menerbitkan penelitian berkualitas tinggi dan inovatif di garis depan semua ilmu pengetahuan dengan penekanan pada penelitian interdisipliner, terutama manuskrip yang terletak pada antarmuka ilmu sosial. Ini mencakup berbagai topik penelitian, seperti: pendidikan, politik, hukum, agama, budaya, dan kebijakan publik, termasuk ilmu pengetahuan alam tentang ilmu sosial.

\section{Tujuan Utama}

Tujuan utama JIP adalah untuk menyebarluaskan pengetahuan ilmiah dan menghasilkan debat dalam konteks interdisipliner, menghubungkan berbagai bidang ilmu sosial. 
Dengan demikian, kontribusi ini akan membantu pengembangan masyarakat dengan dasar ilmiah yang ketat, terbukti secara internasional. Selain itu, untuk menawarkan forum multidisiplin kepada para sarjana dan ahli dari berbagai bidang dan untuk menjembatani kesenjangan di antara mereka, di dalam dan di semua aspek ilmu.

\section{PERNYATAAN ETIKA DAN MALPRAKTEK PUBLIKASI}

Jurnal IImiah Peuradeun (JIP), Jurnal Internasional IImu Sosial, adalah jurnal peer-review dan akses terbuka terkemuka, online dan cetak. Tujuan utama JIP adalah untuk menyebarluaskan pengetahuan ilmiah dan menghasilkan debat dalam konteks interdisipliner, menghubungkan berbagai bidang ilmu sosial. Dengan demikian, kontribusi ini akan membantu pengembangan masyarakat dengan dasar ilmiah yang ketat, terbukti secara internasional. Pernyataan ini mengklarifikasi perilaku etis dari semua pihak yang terlibat dalam tindakan menerbitkan artikel dalam jurnal, yaitu: penulis, pemimpin redaksi, peer-reviewer dan penerbit (SCAD Independent). Pernyataan ini didasarkan pada Kode Etik COPE (Komite Etika Publikasi) dan Pedoman Praktik Terbaik untuk Editor Jurnal.

Esensi utama etika penerbitan JIP untuk semua kelompok yang terlibat dalam proses penerbitan adalah sebagai berikut:

\section{Pedoman Etika untuk Publikasi Jurnal}

Publikasi sebuah artikel dalam JIP yang ditinjau sejawat merupakan blok bangunan penting dalam pengembangan jaringan pengetahuan yang koheren dan dihormati. Ini adalah cerminan langsung dari kualitas karya penulis dan lembaga yang 
mendukung mereka. Artikel yang diulas rekan mendukung dan terwujud dalam metode ilmiah. Karena itu penting untuk menyepakati standar perilaku etis yang diharapkan untuk semua pihak yang terlibat dalam tindakan penerbitan: penulis, editor jurnal, peer reviewer, penerbit, dan masyarakat.

SCAD Independent sebagai penerbit Jurnal IImiah Peuradeun menjalankan tugasnya sebagai perwalian dengan sangat serius dan kami menyadari tanggung jawab etis dan tanggung jawab kami lainnya. Kami berkomitmen untuk memastikan bahwa iklan, cetak ulang, atau pendapatan komersial lainnya tidak berdampak atau memengaruhi keputusan editorial. Selain itu, Dewan Editorial dan SCAD Independent akan membantu dalam komunikasi dengan jurnal dan / atau penerbit lain di mana ini berguna dan perlu.

\section{Keputusan Publikasi}

Editor Jurnal Ilmiah Peuradeun bertanggung jawab untuk memutuskan artikel mana yang diserahkan ke jurnal yang harus diterbitkan. Validasi karya yang dipertanyakan dan pentingnya bagi peneliti dan pembaca harus selalu mendorong keputusan tersebut. Para editor dapat dipandu oleh kebijakan dewan editorial jurnal dan dibatasi oleh persyaratan hukum yang akan berlaku terkait pencemaran nama baik, pelanggaran hak cipta, dan plagiarisme. Editor dapat berunding dengan editor atau pengulas lain dalam membuat keputusan ini. Pernyataan ini mengklarifikasi perilaku etis dari semua pihak yang terlibat dalam tindakan menerbitkan artikel dalam jurnal ini, termasuk penulis, pemimpin redaksi, Dewan Editorial, peer-reviewer dan penerbit (SCAD Independent). Pernyataan ini didasarkan pada Pedoman Praktik Terbaik COPE untuk Editor Jurnal. 


\section{TUGAS EDITOR:}

Tanggungjawab: Editor Jurnal memegang posisi vital dalam mengambil keputusan editorial penting pada semua peer-review yang diajukan untuk publikasi.

Fair Play: Seorang editor setiap saat mengevaluasi naskah untuk konten intelektual mereka tanpa memandang ras, jenis kelamin, orientasi seksual, kepercayaan agama, asal etnis, kewarganegaraan, atau filosofi politik penulis. Editor harus mengevaluasi naskah secara objektif berdasarkan prestasi akademis mereka bebas dari kepentingan komersial atau kepentingan pribadi.

Kerahasiaan: Editor dan staf editorial tidak boleh mengungkapkan informasi apa pun tentang naskah yang dikirimkan kepada siapa pun selain penulis, pengulas, calon pengulas, penasihat editorial lain, dan penerbit, yang sesuai.

Pengungkapan dan Konflik Kepentingan: Materi yang tidak dipublikasikan yang diungkapkan dalam naskah yang dikirimkan tidak boleh digunakan dalam penelitian editor sendiri tanpa persetujuan tertulis dari penulis.

Transparency Academic: Editor harus menjaga transparansi penelitian \& catatan akademis, menghalangi kebutuhan profesional untuk bekerjasama dengan standar etika, dan selalu bersedia mempublikasikan pencabutan, pembetulan, dan perbaikan ketika diperlukan.

Ketelitian: Mempromosikan kejujuran penelitian harus dilestarikan. Jika pada tahap apa pun penerbit mencurigai adanya kesalahan dalam penelitian, maka harus segera diselidiki secara 
rinci dengan otoritas yang sesuai; dan jika ada tindakan pelanggaran yang mencurigakan diamati dalam peer review, itu harus diselesaikan dengan tekun.

\section{TUGAS PENINJAU:}

Kontribusi terhadap Keputusan Editorial: Peer review membantu editor dalam membuat keputusan editorial dan melalui komunikasi editorial dengan penulis juga dapat membantu penulis dalam memperbaiki naskah.

Promptness: Setiap wasit terpilih yang merasa tidak memenuhi syarat untuk meninjau penelitian yang dilaporkan dalam sebuah naskah atau mengetahui bahwa peninjauan yang cepat tidak mungkin dilakukan harus memberi tahu editor dan minta izin dari proses peninjauan.

Kerahasiaan: Naskah yang diterima untuk ditinjau harus diperlakukan sebagai dokumen rahasia. Mereka tidak boleh diperlihatkan atau didiskusikan dengan orang lain kecuali sebagaimana diizinkan oleh editor. Karena peer review bersifat rahasia, reviewer juga tidak boleh berbagi informasi tentang review dengan siapa pun tanpa izin dari editor.

Standar Objektivitas: Tinjauan harus dilakukan secara objektif, memberikan evaluasi yang terperinci, kritis, konstruktif, dan tidak memihak pada waktu yang tepat pada konten ilmiah dari karya tersebut. Wasit harus mengekspresikan pandangan mereka dengan jelas dengan argumen yang mendukung.

Pengakuan Sumber: Peninjau harus mengidentifikasi karya yang diterbitkan relevan yang belum dikutip oleh penulis. Setiap 
pernyataan melalui pengamatan, derivasi, atau argumen telah dilaporkan sebelumnya harus disertai dengan kutipan yang relevan. Peninjau juga harus meminta perhatian editor tentang kesamaan substansial atau tumpang tindih antara manuskrip yang sedang dipertimbangkan dan naskah lain yang diterbitkan yang memiliki pengetahuan pribadi; dan juga memberi tahu editor jurnal tentang segala keprihatinan etis dalam evaluasi naskah yang diserahkan; seperti pelanggaran perlakuan etis terhadap hewan atau manusia.

Pengungkapan dan Konflik Kepentingan: Informasi atau ide yang diperoleh secara istimewa yang diperoleh melalui peer review harus dijaga kerahasiaannya dan tidak digunakan untuk keuntungan pribadi. Peninjau tidak boleh mempertimbangkan naskah di mana mereka memiliki konflik kepentingan yang timbul dari persaingan, kolaborasi, atau hubungan atau koneksi lain dengan penulis, perusahaan, atau lembaga mana pun yang terhubung dengan naskah. Peninjau memberi tahu editor jurnal tentang konflik kepentingan finansial atau pribadi dan menolak untuk meninjau ulang manuskrip ketika ada kemungkinan konflik semacam itu.

\section{TUGAS PENULIS:}

Standar pelaporan: Penulis laporan penelitian asli harus menyajikan akun yang akurat tentang pekerjaan yang dilakukan serta diskusi objektif tentang signifikansinya. Data yang mendasarinya harus diwakili secara akurat di koran. Sebuah naskah harus memuat detail dan referensi yang cukup untuk memungkinkan orang lain mereplikasi karya tersebut. Pernyataan palsu atau sengaja tidak akurat merupakan perilaku yang tidak etis dan tidak dapat diterima. 
Akses dan Retensi Data: Penulis diminta untuk memberikan data mentah sehubungan dengan naskah untuk tinjauan editorial, dan harus siap untuk memberikan akses publik ke data tersebut (konsisten dengan Pernyataan SCAD Independent tentang Data dan Database), jika dapat dilakukan, dan dalam hal apa pun harus siap untuk menyimpan data tersebut untuk waktu yang wajar setelah publikasi.

Orisinalitas dan Plagiarisme: Penulis harus memastikan bahwa mereka telah menulis karya asli seluruhnya, dan jika penulis telah menggunakan karya dan/ atau kata-kata orang lain bahwa ini telah dikutip atau dikutip dengan tepat.

Publikasi Berganda, Redundan, atau Bersamaan: Seorang penulis tidak boleh secara umum menerbitkan manuskrip yang pada dasarnya menggambarkan penelitian yang sama di lebih dari satu jurnal atau publikasi primer. Menyerahkan naskah yang sama ke lebih dari satu jurnal secara bersamaan merupakan perilaku penerbitan yang tidak etis dan tidak dapat diterima.

Pengakuan Sumber: Pengakuan yang tepat atas karya orang lain harus selalu diberikan. Penulis harus mengutip publikasi yang berpengaruh dalam menentukan sifat dari karya yang dilaporkan.

Karangan Naskah: Karangan harus dibatasi untuk mereka yang telah membuat kontribusi signifikan terhadap konsepsi, desain, pelaksanaan, atau interpretasi penelitian yang dilaporkan. Semua yang telah memberikan kontribusi signifikan harus terdaftar sebagai rekan penulis. Di mana ada orang lain yang telah berpartisipasi dalam aspek substantif tertentu dari proyek penelitian, mereka harus diakui atau terdaftar sebagai kontributor. Penulis yang sesuai harus memastikan bahwa semua 
penulis bersama yang sesuai dan tidak ada penulis bersama yang tidak pantas dimasukkan dalam naskah ini, dan bahwa semua penulis bersama telah melihat dan menyetujui versi final dari naskah ini dan telah menyetujui pengajuannya untuk publikasi.

Bahaya dan Subjek Manusia atau Hewan: Jika pekerjaan melibatkan bahan kimia, prosedur atau peralatan yang memiliki bahaya yang tidak biasa yang melekat dalam penggunaannya, penulis harus secara jelas mengidentifikasi hal ini dalam naskah.

Pengungkapan dan Konflik Kepentingan: Semua penulis harus mengungkapkan dalam manuskrip mereka setiap konflik kepentingan finansial atau substantif lainnya yang mungkin ditafsirkan untuk memengaruhi hasil atau interpretasi naskah mereka. Semua sumber dukungan keuangan untuk proyek harus diungkapkan.

Kesalahan Mendasar dalam Karya yang Diterbitkan: Ketika seorang penulis menemukan kesalahan atau ketidakakuratan yang signifikan dalam karya-karyanya yang diterbitkan, adalah kewajiban penulis untuk segera memberi tahu editor jurnal atau penerbit dan bekerjasama dengan editor untuk menarik kembali atau memperbaiki kertas.

Izin: Penulis yang ingin menyertakan gambar, tabel, atau teks bagian yang telah diterbitkan di tempat lain diharuskan untuk mendapatkan izin dari pemilik hak cipta untuk format cetak dan online dan untuk menyertakan bukti bahwa izin tersebut telah diberikan ketika mengirimkan surat-surat mereka. Setiap materi yang diterima tanpa bukti tersebut akan dianggap berasal dari penulis. 
How to Get Your Research Published and Then Noticed

26 


\section{Siapkan Naskah Anda}

\section{NASKAH ANDA}

\section{Judul}

Judul adalah iklan utama untuk artikel Anda. Judul yang bagus mengajak pembaca untuk membaca; artikel dengan judul yang buruk mungkin tidak akan pernah mencapai target pembaca. Judul artikel Anda harus mencerminkan kontennya dengan jelas, memungkinkan pembaca untuk memutuskan apakah itu relevan bagi mereka.

Buat judulnya menarik dan tetap spesifik. Tinggalkan frasa seperti study studi ', investigasi ', dan pengamatan '; dan hindari menggunakan singkatan dan jargon. Ingat juga, bahwa layanan abstrak dan pengindeksan bergantung pada judul yang akurat; mereka mengekstrak kata kunci dari mereka untuk referensi silang.

Pada dasarnya, judul yang efektif:

1. Identifikasi masalah utama artikel.

2. Mulailah dengan pokok bahasan artikel.

3. Apakah akurat, tidak ambigu, spesifik dan (bila mungkin) lengkap.

4. Sesingkat mungkin.

5. Menarik dan menarik; mereka membuat orang ingin membaca lebih lanjut. 


\section{Penulis}

Hanya penulis yang telah membuat kontribusi intelektual untuk penelitian yang dapat dikreditkan; mereka yang akan bertanggung jawab atas data dan kesimpulan, dan yang telah menyetujui naskah final. Urutan nama yang dikreditkan dapat bervariasi antar disiplin ilmu; penulis yang sesuai mungkin tidak selalu menjadi penulis pertama.

\section{Abstrak}

Abstrak adalah kesempatan Anda untuk mendeskripsikan penelitian Anda dalam 200 kata - jadi gunakan dengan bijak. Bersama-sama, judul dan abstrak harus dapat sepenuhnya mewakili artikel Anda, termasuk untuk digunakan oleh layanan pengindeksan. Banyak penulis menulis abstrak terakhir, sehingga mencerminkan konten secara akurat.

Abstrak harus meringkas masalah atau tujuan penelitian Anda, dan metode, hasil, dan kesimpulannya. Biasanya abstrak tidak menyertakan referensi, angka, atau tabel. Itu harus menyebutkan setiap bagian penting dari artikel, dengan cukup detail bagi pembaca untuk memutuskan apakah akan membaca seluruh naskah atau tidak. Meskipun hebat membuat abstraknya menarik, di atas semua itu harus akurat. Jangan menjanjikan lebih dari yang disampaikan oleh artikel Anda.

\section{Kata Kunci}

Kebanyakan jurnal meminta kata kunci; kata-kata penting yang, bersama dengan yang ada di judul, menangkap penelitian secara efektif. Kata kunci digunakan oleh layanan abstrak dan 
pengindeksan; memilih yang tepat dapat meningkatkan peluang artikel Anda ditemukan oleh peneliti lain. Banyak jurnal juga meminta klasifikasi subjek selama proses pengiriman online; ini membantu editor untuk memilih pengulas.

\section{Badan Naskah}

Buat pengantar singkat. Itu harus memberikan konteks dan latar belakang, tetapi tidak menjadi pelajaran sejarah. Ini harus menyatakan masalah yang sedang diselidiki, latar belakang kontekstualnya, dan alasan untuk melakukan penelitian. Nyatakan pertanyaan yang Anda jawab dan jelaskan setiap temuan orang lain yang Anda tantang atau lanjutkan. Secara singkat dan logis arahkan pembaca ke hipotesis, pertanyaan penelitian, dan desain atau metode eksperimental Anda.

\section{Metode}

(Juga disebut Bahan dan Metode atau Metode Eksperimental)

Bagian ini harus cukup rinci sehingga pembaca dapat mereplikasi penelitian Anda, dan menilai apakah metode itu membenarkan kesimpulan. Dianjurkan untuk menggunakan lampau ini tentang apa yang Anda lakukan - dan hindari menggunakan orang pertama, meskipun ini akan bervariasi dari jurnal ke jurnal.

Pada akhirnya, Anda harus menjelaskan bagaimana Anda mempelajari masalah, mengidentifikasi prosedur yang Anda ikuti, dan menyusun informasi ini se-logik mungkin. Jika metode Anda baru, Anda harus menjelaskannya secara rinci. Jika sudah dipublikasikan sebelumnya, kutip karya asli, termasuk amandemen Anda jika Anda telah membuat modifikasi. Identifikasi peralatan dan bahan yang Anda gunakan, tentukan sumbernya. Sebutkan 
frekuensi pengamatan dan jenis data apa yang dicatat. Berikan pengukuran yang tepat, nyatakan kekuatan dan kelemahannya jika perlu. Beri nama setiap uji statistik, sehingga hasil kuantitatif Anda dapat dinilai.

Jika penelitian Anda melibatkan peserta manusia, hewan, sel punca atau bahan biohazard lainnya, Anda harus memasukkan informasi tertentu dalam pernyataan etika, seperti persetujuan komite dan izin untuk menerbitkan. Anda juga harus menjelaskan kriteria Anda untuk memilih peserta.

\section{Hasil}

Bagian ini harus menyajikan temuan Anda secara objektif, menjelaskan sebagian besar dalam teks. Di sinilah Anda menunjukkan bagaimana hasil Anda berkontribusi pada tubuh pengetahuan ilmiah, jadi jelas dan logis. Dan penting untuk tidak menafsirkan hasil Anda - yang ada di bagian Diskusi \& Kesimpulan.

Anda dapat mendasarkan urutan teks ini pada tabel, angka, dan grafik yang paling baik menyajikan temuan Anda. Tekankan setiap temuan signifikan dengan jelas. Tabel dan angka harus diberi nomor secara terpisah; angka-angka harus memiliki deskripsi yang singkat namun lengkap - legenda - yang mengungkapkan bagaimana data diproduksi.

\section{Diskusi \& Kesimpulan}

Di sinilah Anda menggambarkan makna hasil Anda, terutama dalam konteks apa yang sudah diketahui tentang subjek. Anda dapat memberikan kesimpulan umum dan spesifik, tetapi berhati-hatilah untuk tidak meringkas artikel Anda itulah gunanya abstrak. 
Anda harus menautkan bagian ini kembali ke pendahuluan, merujuk pada pertanyaan atau hipotesis Anda, dan membahas bagaimana hasilnya terkait dengan harapan Anda dan sumber yang dikutip. Apakah hasilnya mendukung atau bertentangan dengan teori yang ada? Apakah ada batasannya? Anda juga dapat menyarankan eksperimen, penggunaan, dan ekstensi lebih lanjut.

Yang terpenting, diskusi harus menjelaskan bagaimana riset Anda telah menggerakkan tubuh pengetahuan ilmiah ke depan. Kesimpulan Anda harus dapat didukung dan tidak melampaui hasil Anda, jadi hindari spekulasi yang tidak semestinya dan penilaian yang berani tentang dampak. Ini juga merupakan tempat yang baik untuk menyarankan aplikasi praktis untuk hasil Anda, dan untuk menjabarkan apa langkah selanjutnya dalam penelitian Anda.

Untuk meringkas, pastikan bahwa:

1. Hasil Anda secara langsung mendukung kesimpulan Anda.

2. Anda menggunakan ekspresi spesifik dan deskripsi kuantitatif - '12 derajat lebih tinggi 'daripada' suhu lebih tinggi'.

3. Anda hanya mendiskusikan apa yang Anda definisikan di awal naskah ini - jangan memperkenalkan pembaca pada kosa kata yang sama sekali baru.

4. Jika Anda melewatkan istilah penting, kembali ke pendahuluan dan masukkan.

5. Semua interpretasi dan spekulasi didasarkan pada fakta, bukan imajinasi. 


\section{Ucapan Terima Kasih}

Buat ucapan terima kasih singkat, beri nama mereka yang membantu penelitian Anda; kontributor, atau pemasok yang menyediakan materi gratis. Anda juga harus mengungkapkan setiap konflik kepentingan finansial atau substantif lainnya yang dapat dilihat memengaruhi hasil atau interpretasi Anda.

\section{Referensi}

Penelitian baru dibangun di atas karya yang diterbitkan sebelumnya, yang harus selalu diakui. Informasi apa pun yang bukan 'pengetahuan umum', atau dihasilkan oleh eksperimen Anda, harus dikenali dengan kutipan; dan teks yang dikutip harus dalam tanda kutip, dan termasuk referensi. Format kutipan dan referensi berbeda-beda, jadi Anda harus merujuk pada Panduan untuk Penulis untuk jurnal yang Anda kirimkan, dalam hal ini adalah JIP.

\section{KUALITAS BAHASA}

Artikel ilmiah harus melaporkan temuan dan kesimpulan Anda sejelas dan setepat mungkin. Untuk mencapai ini:

1. Cobalah untuk menghindari kata atau frasa yang tidak perlu - jaga agar tetap sederhana.

2. Gunakan tulisan aktif jika memungkinkan. Sebagai contoh, 'Karbon dioksida dikonsumsi oleh tanaman' adalah pasif. Tulisan aktif mempersingkat frasa ini menjadi, 'Tumbuhan mengkonsumsi karbon dioksida' yang jauh lebih tajam. 
3. Tegang itu penting. Untuk fakta dan hipotesis yang diketahui, gunakan present tense: 'Harapan hidup ratarata seekor lebah madu adalah enam minggu.' Tetapi gunakan tense masa lalu ketika merujuk pada eksperimen yang telah Anda lakukan: 'Semua lebah madu dipelihara di lingkungan dengan suhu yang konsisten $23^{\circ} C$. 'Dan juga gunakan lampau untuk menggambarkan hasil: 'Rentang hidup rata-rata lebah di lingkungan kita yang terkandung adalah delapan minggu'.

\section{ILUSTRASI}

Mengirimkan ilustrasi, gambar, atau karya seni lainnya seperti multimedia dan file pelengkap - dalam format elektronik berarti bahwa kami dapat menghasilkan karya Anda dengan standar terbaik, memastikan akurasi, kejelasan, dan detail tingkat tinggi. Layanan ilustrasi profesional kami dapat membuat atau memoles gambar agar sesuai dengan kebutuhan Anda. Kami mendukung gambar penuh warna dan fotorealistik rinci dari sketsa, atau mengubah gambar yang ada menjadi gambar garis yang lebih sederhana.

\section{MENAMBAHKAN DATA PENELITIAN}

Data penelitian membentuk tulang punggung artikel penelitian Anda dan memberikan fondasi di mana pengetahuan ilmiah, teknis, dan medis dibangun. Sebagai seorang peneliti, Anda semakin didorong, atau bahkan diberi mandat, untuk membuat data riset Anda tersedia, dapat diakses, dapat ditemukan, dan dapat digunakan. Sebagai seorang penulis, Anda dapat memilih untuk menyimpan data Anda di repositori, seperti 
Mendeley Data, untuk membuat dataset Anda dapat dicoba secara mandiri dan menautkannya dengan artikel Anda. Anda juga dapat memilih untuk mengirimkan artikel data singkat yang diulas sejawat. Artikel data Anda akan diindeks dan ditautkan dengan artikel penelitian asli Anda. Pastikan untuk mengutip data penelitian Anda di artikel Anda. Ini memastikan Anda menerima kredit untuk pekerjaan Anda, sekaligus membuat data penelitian Anda dapat diakses, memberi wawasan lebih dalam kepada pembaca Anda dan mendukung pekerjaan mereka.

\section{PERNYATAAN DATA}

Mungkin ada alasan mengapa Anda tidak dapat membagikan data penelitian Anda, misalnya karena alasan kerahasiaan. Dalam hal ini Anda dapat mengirimkan pernyataan data dengan akan muncul di sebelah artikel Anda dan menyatakan alasan mengapa dataset Anda tidak ditautkan ke artikel Anda.

\section{ETIKA}

Memahami batasan-batasan dalam penelitian dan penerbitan ilmiah adalah langkah kunci untuk memastikan pekerjaan Anda dimulai dari awal. Pelanggaran ilmiah dan pelanggaran etika penerbitan dapat terjadi dalam berbagai bentuk, dan dilakukan secara sadar atau tidak sadar. Contoh kesalahan dan pelanggaran meliputi:

1. Sengketa kepengarangan - dengan sengaja salah menggambarkan hubungan ilmuwan dengan karya yang diterbitkan. 
2. Kepentingan yang bersaing - tidak mengungkapkan kepada jurnal bahwa Anda memiliki konflik langsung atau tidak langsung yang mencegah Anda menjadi tidak memihak.

3. Plagiarisme - menyerahkan karya atau ide orang lain sebagai milik Anda.

4. Pengajuan simultan - mengirimkan naskah ke lebih dari satu publikasi secara bersamaan.

5. Penipuan penelitian - termasuk pemalsuan (membuat data penelitian) dan pemalsuan (memanipulasi data penelitian, tabel atau gambar).

6. Salami slicing - 'slicing-up' penelitian yang akan membentuk satu naskah yang bermakna menjadi beberapa naskah yang berbeda. 
How to Get Your Research Published and Then Noticed 


\section{Kirim dan Perbaiki Naskah Anda}

Setelah Anda memeriksa dengan baik, naskah anda siap untuk dikirimkan ke editor jurnal melalui sistem pengiriman dan siap mengikuti proses peer review.

\section{BAGAIMANA MENGIRIMKAN NASKAH?}

Pengajuan ke Jurnal Ilmiah Peuradeun melalui sistem pengajuan elektronik yang memungkinkan untuk peninjauan editorial sepenuhnya online dan proses pengambilan keputusan. Jurnal saat ini menggunakan platform OJS oleh PKP.

Tertarik mengirimkan ke jurnal ini? Kami menyarankan Anda meninjau tentang halaman Jurnal Ilmiah Peuradeun (JIP) untuk kebijakan bagian jurnal, serta Pedoman Penulis. Penulis perlu mendaftar dengan jurnal sebelum mengirimkan atau, jika sudah terdaftar, cukup login dan memulai proses lima langkah.

Pengajuan naskah ke jurnal ini menyiratkan bahwa naskah belum masuk atau diserahkan ke jurnal lain dan penulis telah memperoleh izin yang sesuai untuk menggunakan data yang diperoleh dan terkandung dalam naskah. Dengan ketentuan sebagai berikut:

1. Penting bagi penulis untuk menyiapkan naskah sesuai dengan spesifikasi yang ditetapkan. Kegagalan untuk mengikuti dapat menyebabkan naskah Anda tertunda dan keefektifan kemampuan pencarian yang ditawarkan oleh 
pengiriman elektronik akan tergantung pada perawatan yang digunakan oleh penulis dalam menyiapkan naskah;

2. Penggunaan bahasa Inggris yang lancar, dapat dipahami, dan benar adalah kriteria utama. Penulis harus memastikan bahwa naskah tidak memiliki masalah bahasa. Kalau tidak, ditolak di pra-penilaian. Proofreading sangat disarankan;

3. Naskah harus disiapkan dalam Microsoft Word (menggunakan templat JIP) dan diserahkan melalui situs web JIP. JIP hanya menerima pengiriman elektronik (online). Oleh karena itu, penulis harus masuk sebelum mengirimkan artikel mereka. Silakan klik di siniuntuk masuk;

4. Pengajuan harus dalam bahasa Inggris berdasarkan gaya yang digariskan oleh American Psychological Association (edisi ke-6). Dokumen yang tidak sesuai dengan kriteria pengajuan jurnal akan dikembalikan ke pengirim untuk diperbaiki;

5. Jurnal Ilmiah Peuradeun adalah jurnal akses terbuka ilmiah peer-review - bukan jurnal komersial. Tetapi proses pembaruan, perluasan kapasitas, peningkatan teknis dan pemeliharaan harian jurnal membutuhkan dana;

6. Semua artikel yang dikirimkan ke JIP akan ditinjau oleh rekan sejawat. JIP menganut proses peer-review doubleblind sesuai dengan standar internasional. Baik resensi maupun penulisnya adalah anonim. Anonimitas penulis mencegah bias resensi, misalnya berdasarkan negara asal penulis atau karya kontroversial sebelumnya. (Baca Proses Review). Artikel yang ditulis oleh penulis bergengsi atau terkenal dianggap berdasarkan isi naskah mereka, bukan 
reputasi mereka. Wasit anonim dipilih oleh pemimpin redaksi dan harus bebas biaya yaitu wasit sukarela.

Biasanya hasil akhir dari tinjauan naskah dikirim ke penulis dalam waktu 4-5 minggu hari kerja. Jika diperlukan revisi, penulis diminta untuk menyerahkan kembali naskah yang direvisi dengan memasukkan saran dan rekomendasi dari peer-reviewer. Untuk memfasilitasi publikasi yang cepat, penulis diberikan maksimum enam minggu untuk revisi dari tanggal pemberitahuan dan sistem kami akan mengirimkan pengingat setiap dua minggu kepada penulis. Setelah enam minggu, naskah yang direvisi biasanya akan dianggap sebagai kiriman baru.

Penulis naskah yang diterima akan diberi tahu dan akan menerima bukti halaman (PDF) untuk pembacaan bukti sebelum publikasi. Tanggung jawab untuk akurasi dalam salinan akhir ada pada penulis. Semua pengiriman tunduk pada persetujuan akhir dan penerimaan untuk publikasi oleh Pemimpin Redaksi.

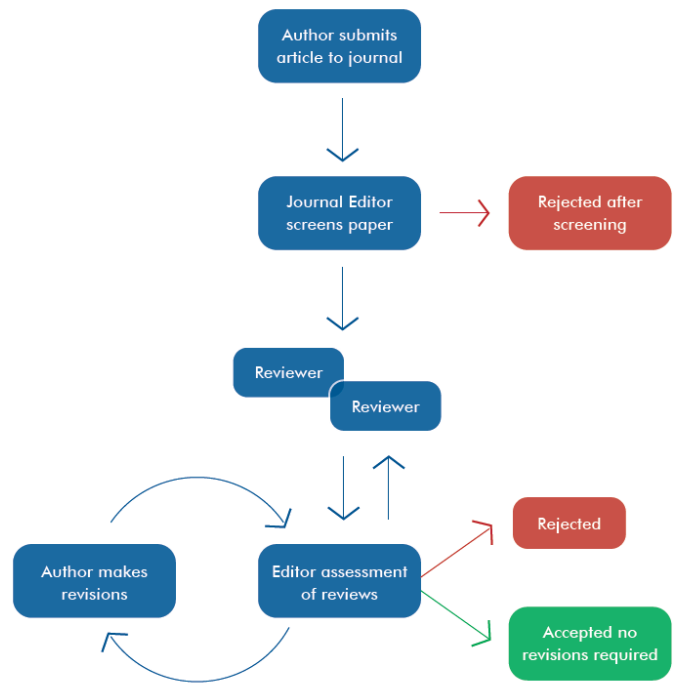




\section{ALUR KERJA EDITOR}

Seluruh alur kerja editorial dilakukan dengan menggunakan Open Journal System (OJS). Alur kerja editorial memberi para Editor wewenang untuk menolak naskah apa pun karena ketidaksesuaian subjeknya, kurangnya kualitas, atau tidak akuratnya hasilnya. Editor tidak dapat menetapkan dirinya sebagai peninjau eksternal naskah. Ini untuk memastikan proses peninjauan sejawat yang berkualitas tinggi, adil, dan tidak memihak dari setiap naskah yang diserahkan ke jurnal, karena setiap naskah harus direkomendasikan oleh dua atau lebih peninjau eksternal bersama dengan Editor yang bertanggung jawab atas naskah tersebut agar dapat untuk diterima untuk publikasi dalam jurnal. Berikut ini adalah Alur Kerja Editorial yang dikirimkan oleh setiap naskah ke jurnal selama proses peer-review.

1. Jurnal Ilmiah Peuradeun (JIP) mengandalkan proses peer review untuk menegakkan kualitas dan validitas artikel yang dipublikasikan. Semua artikel yang dikirimkan ke JIP akan ditinjau oleh rekan sejawat. JIP mematuhi proses DoubleBlind Peer-Review yang cepat dan adil, dan juga memastikan kualitas artikel yang dipublikasikan. Pernyataan ini didasarkan pada Kode Etik COPE (Komite Etika Publikasi) dan Pedoman Etika Praktik Terbaik untuk Peer Reviewer.

2. Satu editor biasanya akan mengambil setiap artikel dari awal hingga selesai. Editor menentukan apakah naskah sesuai dengan fokus dan ruang lingkup jurnal. Selanjutnya pemeriksaan untuk tingkat kesamaan dilakukan dengan menggunakan CrossCheck, didukung oleh iThenticate. Manuskrip yang tidak termasuk dalam jurnal atau berisi plagiarisme, termasuk plagiarisme diri, ditolak. 
3. Para editor membaca semua artikel yang baru diajukan dalam 3-5 hari. Naskah dapat dikembalikan kepada penulis oleh Editor sebelum ditinjau, jika dinilai berada di luar ruang lingkup, di luar batas pedoman panjang kata atau tidak cukup siap untuk publikasi.

4. Jika artikel Anda berpotensi cocok untuk JIP, editor itu akan mengirim artikel Anda ke peer reviewer. Jurnal ini menggunakan sistem double-blind untuk peer-review; identitas pengulas dan penulis tetap anonim. Naskah ini akan ditinjau oleh tiga ahli; dua pengulas dari luar dan satu editor dari jurnal biasanya terlibat dalam meninjau kiriman. Peninjau kemudian akan menyerahkan laporan mereka pada naskah bersama dengan rekomendasi mereka dari salah satu tindakan berikut kepada Editor:

1) Accept Submission;

2) Revisions Required;

3) Resubmit for Review;

4) Resubmit Elsewhere;

5) Decline Submission;

6) See comments.

5. Biasanya hasil akhir dari tinjauan kertas dikirim ke penulis dalam waktu 4-5 minggu hari kerja. Jika diperlukan revisi, penulis diminta untuk menyerahkan kembali naskah yang direvisi dengan memasukkan saran dan rekomendasi dari peer-reviewer.

6. Untuk memfasilitasi publikasi cepat, penulis diberikan maksimum enam minggu untuk revisi dari tanggal pemberitahuan dan sistem kami akan mengirimkan pengingat setiap dua minggu kepada penulis. Setelah 
enam minggu, naskah yang direvisi biasanya akan dianggap sebagai kiriman baru.

7. Naskah yang telah diterima untuk publikasi akan dikirim ke copyediting. Proses copyediting mengedit artikel yang diajukan untuk meningkatkan tata bahasa dan kejelasan penulisan, bekerja dengan Penulis untuk memastikan semuanya ada dan memastikan kepatuhan dalam bibliografi jurnal dan gaya teks, dan menghasilkan salinan yang diedit untuk Layout Editor untuk dikonversi menjadi "dapur" yang akan muncul dalam format publikasi jurnal.

8. Naskah yang telah diterima untuk publikasi akan dikirim ke copyediting. Copyediting melakukan proses pengeditan artikel yang diajukan untuk meningkatkan tata bahasa dan kejelasan penulisan, bekerja dengan Penulis untuk memastikan semuanya ada dan memastikan kepatuhan dalam bibliografi jurnal dan gaya teks, dan menghasilkan salinan yang diedit untuk dikirim ke Editor Layout. Editor Tata Letak melakukan proses tata letak untuk dikonversi menjadi file "dapur" dalam format PDF, HTML yang akan muncul dalam format publikasi jurnal.

9. Sebelum dikirim ke bagian publikasi, naskah akan dikirim ke proofreading untuk dibaca, diperbaiki, dan dipelajari kesalahan penulisan termasuk format penulisan dalam naskah artikel yang dilakukan dengan penulis. Kesalahan tipografi dan format akan diperbaiki oleh editor tata letak. Akhirnya, teks akan dikirim ke Editor Publikasi untuk menentukan jadwal publikasi, memperbarui halaman di situs web, dan memperbarui metadata dari teks terakhir. 
Jurnal ini menggunakan Open Journal Systems 3.0.1.0, yang merupakan manajemen jurnal open source dan perangkat lunak penerbitan yang dikembangkan, didukung, dan didistribusikan secara bebas oleh Proyek Pengetahuan Publik di bawah Lisensi Publik Umum GNU. Untuk alur kerja jurnal ini dapat dilihat pada Bagan tentang Sistem Penerbitan ini.

\section{OJS Editorial and Publishing Process}

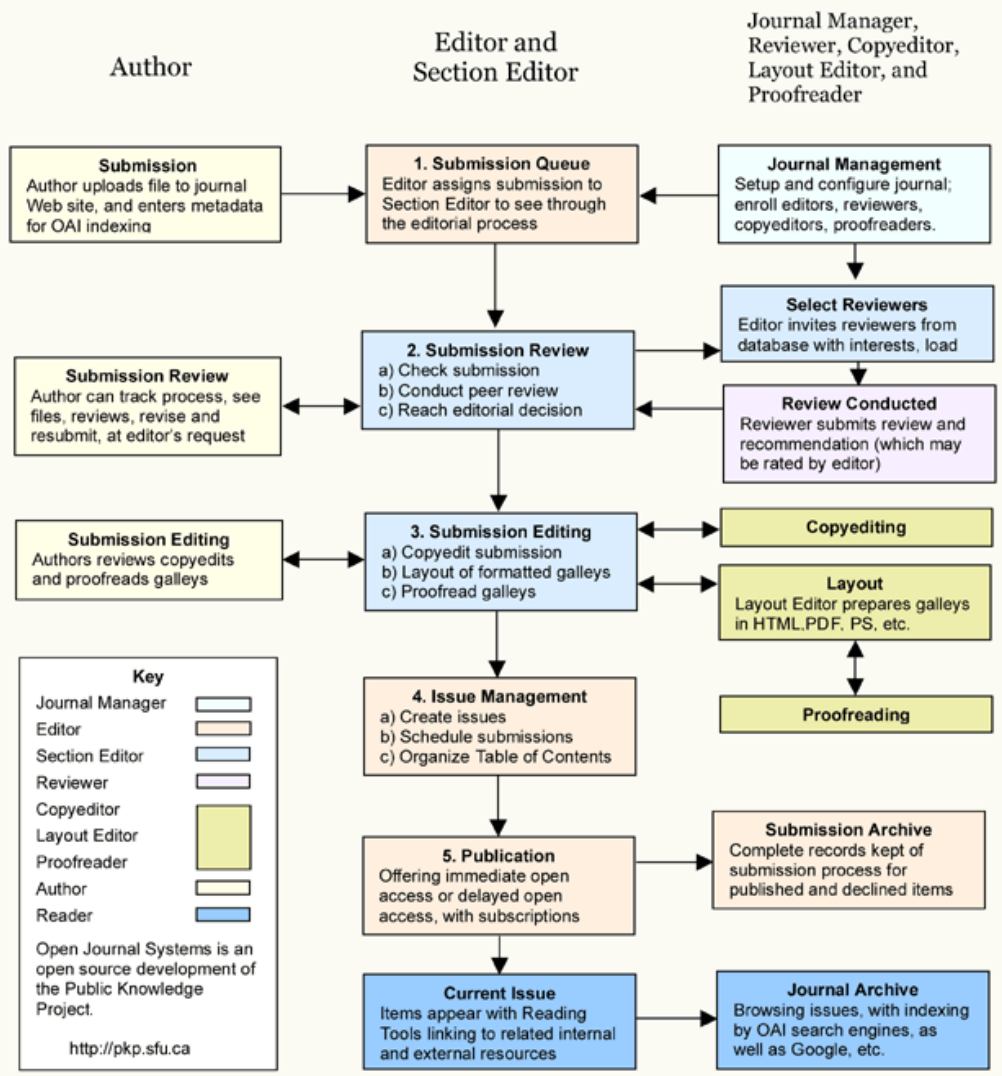




\section{PEER REVIEW}

Setelah penyerahan, setiap naskah diperiksa untuk plagiarisme, dan dinilai dengan cermat untuk menentukan apakah itu sesuai dengan tujuan dan ruang lingkup jurnal. Jika perwakilan jurnal antusias dengan karya tersebut, editor jurnal akan menunjuk reviewer untuk membaca dan mengulas naskah tersebut.

\section{Apa yang dilakukan peer reviewer?}

Reviewer atau peninjau membantu menentukan validitas, signifikansi, dan orisinalitas karya, dan dapat menyarankan perbaikan pada naskah dan penelitian. Atas rekomendasinya, editor akan menerima, menerima dengan revisi, atau menolak naskah.

Untuk membuat penilaian yang baik, pengulas sejawat menggunakan daftar periksa mereka sendiri untuk mengevaluasi konten untuk nilai ilmiah dan orisinalitas, untuk melihat bahwa artikel mematuhi praktik ilmiah umum serta pedoman khusus jurnal, dan untuk memastikan bahwa Anda telah dirujuk dengan benar. Peninjau sejawat akan melihat dengan cermat metodologi dan validitas data Anda, dan mempertimbangkan pendekatan etis Anda. Mereka kemudian akan merekomendasikan perubahan sebelum naskah Anda diterbitkan.

Jurnal Ilmiah Peuradeun (JIP) menganut proses DoubleBlind Peer-Review yang cepat dan adil, dan juga memastikan kualitas artikel yang dipublikasikan. Pernyataan ini didasarkan pada Kode Etik COPE (Komite Etika Publikasi) dan Pedoman 
Etika Praktik Terbaik untuk Peer Reviewer. Setiap naskah yang diserahkan ke Jurnal IImiah Peuradeun ditinjau oleh setidaknya dua pengulas secara independen dalam bentuk "Double-Blind Review". Keputusan untuk publikasi, amandemen, atau penolakan didasarkan pada laporan/ rekomendasi mereka. Dalam kasus tertentu, editor dapat mengirimkan artikel untuk ditinjau ke yang lain, resensi ketiga sebelum membuat keputusan, jika perlu. JIP menerima lebih banyak pengiriman daripada yang dapat dipublikasikan. Dewan Editorial dapat menolak naskah tanpa peer review jika naskah itu dinilai tidak memenuhi kualifikasi minimum jurnal yang disyaratkan.

Proses peer-review adalah Double-Blind Review. Baik resensi maupun penulisnya adalah anonim. Anonimitas penulis mencegah bias resensi, misalnya berdasarkan negara asal penulis atau karya kontroversial sebelumnya. Artikel yang ditulis oleh penulis bergengsi atau terkenal dianggap berdasarkan isi naskah mereka, bukan reputasi mereka. Untuk dipublikasikan di JIP, sebuah naskah harus memenuhi empat (4) kriteria umum:

1. Memberikan bukti kuat untuk kesimpulannya.

2. Kebaruan (kami tidak mempertimbangkan abstrak laporan pertemuan dan pracetak pada server komunitas untuk mengkompromikan hal-hal baru).

3. Sangat penting bagi para ilmuwan di bidang tertentu.

4. Idealnya, menarik bagi para peneliti dalam disiplin ilmu terkait lainnya.

Secara umum, agar dapat diterima, sebuah naskah harus mewakili suatu kemajuan dalam pemahaman yang kemungkinan 
mempengaruhi pemikiran di lapangan. Harus ada alasan yang jelas mengapa karya ini layak mendapat visibilitas publikasi dalam JIP daripada yang terbaik dari jurnal spesialis. Peninjau kemudian akan menyerahkan laporan mereka pada naskah bersama dengan rekomendasi mereka dari salah satu tindakan berikut kepada Editor:

1. Accept Submission;

2. Revisions Required;

3. Resubmit for Review;

4. Resubmit Elsewhere;

5. Decline Submission;

6. See comments.

Peninjau Jurnal IImiah Peuradeun diminta untuk mempertimbangkan hal-hal berikut selama evaluasi:

1. Apakah naskah ini memiliki tujuan dan sasaran/ pertanyaan penelitian yang jelas yang dapat dicapai dalam ruang lingkup naskah Jurnal IImiah Peuradeun?

2. Apakah naskah ini berkontribusi pada pengetahuan?

3. Apakah pekerjaan sesuai didasarkan pada literatur untuk membenarkan kontribusinya dan membingkai analisis/ evaluasi?

4. Apakah metodologi penelitian/ evaluasi dibenarkan, jelas, dan sesuai? (termasuk pertimbangan/ persetujuan etis jika diperlukan)

5. Apakah analisis/ evaluasi memiliki aliran yang jelas dan argumen logis?

6. Apakah analisis/ evaluasi terkait dengan diskusi dan kesimpulan yang tepat? 
7. Apakah disajikan dengan cara yang sesuai untuk audiens Jurnal Ilmiah Peuradeun?

Selain itu, naskah dapat dikembalikan kepada penulis oleh Editor sebelum ditinjau, jika dinilai berada di luar ruang lingkup, di luar batas pedoman panjang kata atau tidak cukup siap untuk publikasi. Untuk memfasilitasi publikasi yang cepat, penulis diberikan maksimal 6 minggu untuk revisi. Setelah 6 minggu, naskah yang direvisi biasanya akan dianggap sebagai kiriman baru.

\section{PRINSIP PENERBITAN}

1. Naskah yang dikirim tidak boleh telah diterbitkan sebelumnya atau tidak boleh diterbitkan di tempat lain. Kalau tidak, penulis akan bertanggung jawab atas ketidaknyamanan;

2. Hak cipta dari naskah yang diterbitkan berkaitan dengan jurnal dan tanggung jawab hukum dan ilmiah menjadi milik penulisnya;

3. Kutipan dapat diambil dari artikel yang dipublikasikan di JIP selama mereka direferensikan.

4. Komite penerbitan akan memeriksa dan menilai artikel yang diserahkan ke jurnal dan jika tidak memenuhi maksud dan tujuan jurnal tidak akan dipertimbangkan;

5. Komite penerbitan memiliki otorisasi untuk membuat perubahan tata bahasa dan ejaan dalam teks, jika perlu;

6. Naskah yang memenuhi kriteria dasar JIP akan dikirim untuk ditinjau oleh Double Blind Review untuk komentar mereka; 
7. Publikasi akhir dari artikel akan diputuskan oleh editor masalah berdasarkan komentar wasit. Jika jumlah artikel melebihi jumlah yang dapat diterbitkan dalam suatu masalah, artikel yang akan diterbitkan akan diputuskan oleh komite penerbit;

8. Setidaknya dua referensi harus menemukan artikel yang diserahkan yang layak untuk diterbitkan;

9. Jika artikel diterima untuk dipublikasikan di JIP dengan koreksi yang diperlukan, artikel tersebut akan dikirim ke penulis dengan komentar wasit secara elektronik. Penulis diharuskan untuk membuat perubahan dan koreksi yang diperlukan dalam naskah dan mengembalikan draf akhir artikel ke JIP dalam periode waktu tertentu. Penulis diizinkan untuk mengajukan keberatan atas komentar dan koreksi atas dasar bukti nyata;

10. Status artikel dapat dilihat di situs web JIP, melalui akun penulis.

\section{TANGGUNG JAWAB PENERBIT}

JIP diterbitkan oleh SCAD Independent dan menghubungkan penelitian dan praktik untuk kepentingan masyarakat. Jangkauan global - Jurnal diterbitkan Akses Terbuka di bawah CC BY 4.0 membantu memaksimalkan penyebaran. Perusahaan ini memenuhi pedoman W3C AA, dan memiliki prinsip-prinsip berikut:

1. SCAD Independent sebagai penerbit JIP berkomitmen untuk bekerja dengan editor jurnal, mendefinisikan dengan jelas peran mereka yang relevan, untuk 
memastikan keputusan yang tepat terkait prosedur publikasi dan menjaga transparansi keputusan editorial.

2. Independen SCAD sebagai penerbit JIP juga memastikan otonomi integritas dan keaslian setiap artikel yang diterbitkan sehubungan dengan:

a. Publikasi dan pendanaan penelitian;

b. Etika dan kejujuran publikasi;

c. Konflik kepentingan;

d. Kerahasiaan;

e. Kepengarangan;

f. Modifikasi artikel;

g. Publikasi konten yang tepat waktu. 
How to Get Your Research Published and Then Noticed 


\section{Setelah Penerimaan: Artikel dalam Pers, Pemeriksaan, Hak Cipta, dan Lisensi}

Selamat! Artikel Anda telah diterima!

Ada beberapa hal lagi yang perlu dipertimbangkan yang dapat mengoptimalkan publikasi karya Anda. Jurnal Ilmiah Peuradeun akan melakukan apa saja untuk membuat artikel Anda dipublikasikan secepat dan seakurat mungkin.

\section{ARTIKEL DI PRESS}

Artikel yang diterima diterbitkan secara online di situs web dan pengindeksan database JIP sebagai 'artikel dalam pers', dan diberi masalah di kemudian hari. Anda dapat melacak artikel dan kutipan Anda selama proses ini.

\section{BUKTI}

Pengoreksian yang akurat dan tanda koreksi yang jelas sangat penting untuk menghasilkan artikel yang berkualitas. Segera setelah artikel Anda dikeset, Anda akan menerima email dengan lampiran PDF dari artikel Anda atau tautan ke sana di sistem pemeriksaan daring kami beserta dengan LAA (Letter of Accepted Article). 


\section{HAK CIPTA DAN LISENSI}

Ketika Anda menerbitkan karya anda dengan Jurnal Ilmiah Peuradeun, Anda masuk ke dalam perjanjian hukum. Ini berarti bahwa kami di JIP dan Anda sebagai penulis setuju untuk hak dan tanggung jawab tertentu, dan berjanji untuk bertindak dengan cara yang sah menurut hukum.

Semua materi yang diterbitkan oleh JIP dilindungi oleh undang-undang hak cipta dan kekayaan intelektual internasional. JIP dilisensikan di bawah Lisensi Internasional Creative Commons 4.0 (CC-BY-SA) atau lisensi yang setara sebagai lisensi optimal untuk publikasi, distribusi, penggunaan, dan penggunaan kembali karya ilmiah. Izin akses di luar lingkup lisensi ini mungkin tersedia di perpustakaan digital dan basis data jurnal akses terbuka.

\section{Perlindungan Hak Cipta}

Hak cipta bertujuan untuk melindungi cara spesifik artikel telah ditulis untuk menggambarkan penelitian dan hasilnya. JIP dan SCAD Independent berkomitmen untuk melindungi dan mempertahankan pekerjaan dan reputasi penulisnya. Kami menganggap serius dugaan pelanggaran, plagiarisme, sengketa etika, dan penipuan.

Hak cipta bertujuan untuk melindungi cara spesifik artikel telah ditulis untuk menggambarkan eksperimen dan hasilnya. JIP dan SCAD Independent berkomitmen kepada para penulisnya untuk melindungi dan mempertahankan pekerjaan serta reputasi mereka dan menangani dugaan pelanggaran, plagiarisme, sengketa etika, dan penipuan dengan sangat serius. 
Jika penulis mengetahui adanya kemungkinan plagiarisme, penipuan, atau pelanggaran, kami sarankan untuk menghubungi kontak JIP atau SCAD Independent mereka yang kemudian dapat berhubungan dengan departemen hukum kami. Perhatikan bahwa lisensi pengguna akses terbuka tertentu dapat mengizinkan penggunaan kembali yang cukup luas yang mungkin dianggap sebagai pelanggaran hak cipta.

\section{Pemberitahuan Hak Cipta}

Penulis yang menerbitkan jurnal ini menyetujui persyaratan berikut:

1. Penulis memiliki hak cipta dan memberikan jurnal hak publikasi pertama dengan karya yang secara simultan dilisensikan di bawah Lisensi Atribusi Creative Commons (CC-BY-SA) yang memungkinkan orang lain untuk berbagi karya dengan pengakuan kepengarangan karya dan publikasi awal dalam hal ini jurnal (Lihat Pengaruh Akses Terbuka);

2. Penulis diizinkan dan didorong untuk memposting pekerjaan mereka secara online (mis., Dalam repositori institusional atau di situs web mereka) sebelum dan selama proses pengiriman, karena dapat menyebabkan pertukaran yang produktif, serta kutipan yang lebih awal dan lebih besar dari karya yang diterbitkan;

3. Penulis dapat membuat pengaturan kontrak tambahan yang terpisah untuk distribusi non-eksklusif versi jurnal yang diterbitkan dari karya tersebut (mis., Mempostingnya ke repositori institusional atau menerbitkannya dalam sebuah 
buku), dengan pengakuan atas karya awalnya publikasi dalam jurnal ini;

4. Semua pandangan yang diungkapkan dalam karya ini adalah pandangan penulis dan bukan dari Dewan Editorial Jurnal IImiah Peuradeun (JIP) atau SCAD Independent. JIP atau SCAD Independent tidak dapat bertanggung jawab atas pandangan, pendapat, dan pernyataan tertulis dari penulis atau peneliti yang diterbitkan dalam JIP.

\section{INFORMASI HAK CIPTA}

Semua artikel yang diterbitkan dalam jurnal ini dilindungi oleh hak cipta, dan dilisensikan di bawah Lisensi Internasional Creative Commons 4.0 (CC-BY-SA) atau lisensi yang setara sebagai lisensi optimal untuk publikasi, distribusi, penggunaan, dan penggunaan kembali karya ilmiah. Izin akses di luar lingkup lisensi ini mungkin tersedia di perpustakaan digital dan basis data jurnal akses terbuka.

\section{Untuk Penulis:}

Penulis memiliki hak cipta dan memberikan jurnal hak publikasi pertama dengan karya yang dilisensikan secara bersamaan di bawah Lisensi Atribusi Creative Commons; Penulis diizinkan dan didorong untuk memposting pekerjaan mereka secara online (misalnya, dalam repositori institusional atau di situs web mereka) sebelum dan selama proses pengiriman, karena dapat menyebabkan pertukaran yang produktif, serta kutipan yang lebih awal dan lebih besar dari karya yang 
diterbitkan dengan pengakuan kepenulisan karya dan publikasi awal dalam jurnal ini.

\section{Untuk pembaca:}

Meskipun saran dan informasi dalam jurnal ini diyakini benar dan akurat pada tanggal publikasi, baik penulis, editor, bukan penerbit dapat menerima tanggung jawab hukum apa pun atas kesalahan atau kelalaian yang mungkin telah terjadi. Penerbit tidak membuat jaminan, tersurat maupun tersirat, sehubungan dengan materi yang terkandung di sini.

\section{Untuk Pustakawan:}

Kami mendorong pustakawan penelitian untuk membuat daftar jurnal ini di antara kepemilikan jurnal elektronik perpustakaan mereka. Selain itu, mungkin perlu dicatat bahwa sistem penerbitan sumber terbuka jurnal ini cocok untuk perpustakaan untuk menampung anggota fakultas mereka untuk digunakan dengan jurnal yang mereka terlibat dalam pengeditan.

\section{LISENSI PENGGUNA AKHIR}

Jika Anda memilih untuk menerbitkan artikel Anda di JIP, Anda juga memilih lisensi pengguna akhir untuk menentukan bagaimana pembaca dapat berbagi dan menggunakan artikel Anda tanpa harus meminta izin. JIP dilisensikan di bawah Lisensi Internasional Creative Commons 4.0 (CC-BY-SA) atau lisensi yang setara sebagai lisensi optimal untuk publikasi, distribusi, penggunaan, dan penggunaan kembali karya ilmiah. Izin akses di luar lingkup lisensi ini mungkin tersedia di perpustakaan digital dan basis data jurnal akses terbuka. 
Lisensi ini memungkinkan siapa pun untuk menulis, memperbaiki, dan membuat kreasi turunan bahkan untuk tujuan komersial, selama kredit yang sesuai dan pengakuan yang tepat terhadap publikasi asli dari jurnal dibuat untuk memungkinkan pengguna untuk melacak kembali ke naskah asli dan penulis.

Anda harus memberikan kredit yang sesuai, memberikan tautan ke lisensi, dan menunjukkan jika ada perubahan. Anda dapat melakukannya dengan cara yang masuk akal, tetapi tidak dengan cara apa pun yang menunjukkan bahwa pemberi lisensi mendukung Anda atau penggunaan Anda. Jika Anda mencampur, mengubah, atau membangun di atas materi, Anda harus mendistribusikan kontribusi Anda di bawah lisensi yang sama seperti aslinya.

Pembaca juga diberikan akses penuh untuk membaca dan mengunduh manuskrip yang diterbitkan, mencetak ulang, dan mendistribusikan manuskrip dalam media atau format apa pun.

\section{Apa itu Proses Lisensi?}

\section{Langkah 1:}

Penulis menandatangani perjanjian penerbitan di mana mereka akan mempertahankan hak cipta tetapi memberikan hak penerbitan kepada penerbit

\section{Langkah 2:}

Pembaca dapat menggunakan dan berbagi artikel seperti yang didefinisikan oleh lisensi pengguna.

\section{Langkah 3:}

Penulis memberikan penerbit hak untuk menerbitkan artikel di bawah lisensi yang berlaku. 


\section{Langkah 4:}

Penerbit membuat artikel tersedia online dengan lisensi pengguna penulis.

\section{AUTHOR}

Retains copyright

\section{USER LICENSE}

Publishes article under the user

\section{PUBLISHER}

Grants publishing

rights license

READER/USER

Granted rights to

reuse the article

\section{PERNYATAAN PRIVASI}

Informasi pribadi yang dikumpulkan oleh JIP ditangani sesuai dengan Undang-Undang Privasi dan Perlindungan Informasi Pribadi. Menghargai privasi Anda dan melindungi informasi pribadi Anda adalah prioritas bagi kami.

Nama dan alamat email yang dimasukkan di situs JIP akan digunakan secara eksklusif untuk tujuan jurnal ini dan tidak akan tersedia untuk tujuan lain apa pun atau ke pihak lain.

Setiap informasi yang diterima melalui situs web JIP akan disimpan dengan aman menggunakan metode dan perlindungan yang cukup aman dan praktis. Manajemen informasi pribadi JIP diatur oleh Independent SCAD, yang berafiliasi dengan Freedom of Information dan Protection of Privacy Act (FIPPA). JIP tidak akan menjual atau mendistribusikan informasi pribadi Anda kepada 
individu, bisnis, atau entitas pemerintah mana pun, kecuali jika pengungkapan tersebut diharuskan oleh hukum atau terkait dengan penyelidikan atau proses pengadilan atau pemerintah.

\section{PROMOSI PEKERJAAN ANDA}

JIP menerima lebih banyak pengiriman artikel ilmiah setiap tahun daripada yang dapat dipublikasikan. Jadi semakin penting bagi Anda untuk menemukan cara untuk membuat artikel Anda menonjol. Mempromosikan penelitian Anda tidak dimulai setelah naskah Anda selesai dan telah dipublikasikan secara online. Itu harus ada di pikiran Anda bahkan ketika Anda melakukannya dan menulis makalah Anda. Mempromosikan penelitian Anda juga berlanjut setelah dipublikasikan dan melacak kinerja kegiatan promosi Anda akan membantu mendorong hasil.

\section{Bagikan Paper Anda}

Berbagi penelitian dan temuan Anda dapat membantu Anda membuat dampak yang lebih besar di komunitas Anda, yang mengarah pada kolaborasi yang lebih baik, ide-ide baru dan inovasi potensial. Jutaan peneliti memiliki akses ke publikasi formal Anda yang dihosting di SCAD Independent, memungkinkan pengguna menemukan, mengakses, dan mengutip penelitian Anda dalam versi terbaik yang tersedia. Kami mendorong Anda untuk membagikan tautan artikel di media sosial, sehingga itu akan berkontribusi pada skor metrik artikel Anda. Orang-orang penting dapat menemukan Anda dan tautan ke publikasi Anda secara online. JIP dan SCAD Independent mendukung berbagi yang bertanggung jawab dan kami ingin memudahkan Anda untuk membagikan penelitian Anda. 


\section{Pedoman Penulisan JIP}

Jurnal Ilmiah Peuradeun (JIP), diterbitkan tiga kali setahun sejak 2013, jurnal ini adalah jurnal peer-review, open akses, dan spesialisasi dalam Ilmu Sosial. Tujuannya adalah untuk memberikan pembaca pemahaman yang lebih baik bagi dunia. Perkembangan tersebut melalui publikasi artikel, laporan penelitian, dan ulasan buku. Semua makalah yang diajukan harus ditinjau editor, dewan editorial, dan pengulas buta. Kiriman yang melanggar pedoman kami tentang pemformatan atau panjang akan ditolak tanpa ulasan.

\section{PENGAJUAN NASKAH}

1. Penting bagi penulis untuk menyiapkan naskah mereka sesuai dengan spesifikasi yang ditetapkan. Kegagalan untuk mengikuti mereka dapat menyebabkan kertas Anda tertunda dan efektivitas kemampuan pencarian yang ditawarkan oleh pengiriman elektronik akan tergantung pada perawatan yang digunakan oleh penulis dalam menyiapkan naskah mereka;

2. Naskah harus disiapkan dalam Microsoft Word (menggunakan templat JIP) dan dikirimkan melalui situs web JIP. JIP hanya menerima pengiriman elektronik (online). Oleh karena itu, penulis harus masuk sebelum mengirimkan artikel mereka. Silakan kunjungi: http://journal.scadindependent.org/index.php/jipeurad eun/login untuk masuk;

3. Pengajuan harus dalam bahasa Inggris berdasarkan gaya yang digariskan oleh American Psychological Association (edisi ke-6). Dokumen yang tidak sesuai dengan kriteria 
pengajuan jurnal akan dikembalikan ke pengirim untuk diperbaiki;

4. Jurnal Ilmiah Peuradeun (JIP) adalah jurnal akses terbuka ilmiah peer-review - bukan jurnal komersial. Tetapi proses pembaruan, perluasan kapasitas, peningkatan teknis dan pemeliharaan harian jurnal membutuhkan dana;

5. Semua manuskrip melewati tinjauan rekan ganda menurut standar internasional. Baca Proses Peninjauan di:

http://journal.scadindependent.org/index.php/jipeurad eun/reviewprocess

Naskah yang dikirimkan ke editor yang dimuat JIP akan dipertimbangkan jika memenuhi kriteria berikut:

1. Ilmiah Secara karakteristik, ulasan masalah sosial, politik, hukum, agama dan budaya, ide-ide asli, ringkasan hasil penelitian/ survei, dan ulasan buku yang dianggap dapat berkontribusi bagi masyarakat dan ilmu pengetahuan;

2. Naskah yang dikirimkan adalah naskah yang belum pernah dipublikasikan dalam publikasi apa pun atau tidak ada publikasi yang diminta atau dipertimbangkan oleh media lain;

3. Naskah harus ditulis dalam Bahasa Inggris Amerika (Bahasa Inggris AS), tidak lebih dari 5.000 kata (atau panjang maksimal 5.000 kata), termasuk teks, semua tabel dan gambar, catatan, referensi, dan lampiran yang dimaksudkan untuk publikasi. Semua pengiriman harus menyertakan abstrak dan kata kunci dengan menggunakan templat JIP, menggunakan font Book Antiqua ukuran 11 dan dengan spasi 1,2. (Anda dapat mengunduh Template JIP di: www.journal.scadindependent.org. Kutipan, bagian, dan katakata dalam bahasa lokal atau asing harus diterjemahkan ke dalam bahasa Inggris; 
4. Setiap naskah ditulis secara berurutan, terdiri dari judul, nama penulis, abstrak, kata kunci, konten (Pendahuluan, Metode, Temuan Penelitian, Diskusi, Kesimpulan dan Bibliografi;

5. Judul harus singkat dan to the point, diizinkan untuk menyertakan subtitle dengan total maksimum yang terdiri dari 14 suku kata;

6. Buat nama penulis, afiliasi institusi, dan alamat email di bawah judul artikel, dan Penulis tidak perlu menyertakan gelar akademis;

7. Abstrak: Abstrak singkat dan faktual diperlukan (panjang maksimum 200 kata). Abstraksi harus menyatakan secara singkat tujuan penelitian, hasil utama dan kesimpulan utama. Abstrak sering disajikan terpisah dari artikel, sehingga harus dapat berdiri sendiri. Referensi karenanya harus dihindari, tetapi jika penting, mereka harus dikutip secara penuh, tanpa referensi ke daftar referensi. Singkatan yang tidak standar atau tidak biasa harus dihindari, tetapi jika perlu, singkatan harus didefinisikan pada penyebutan pertama dalam abstrak itu sendiri;

8. Kata kunci: Segera setelah abstrak, berikan maksimal lima kata kunci, hindari istilah umum dan jamak dan beberapa konsep (hindari, misalnya, 'dan', 'dari'). Hemat dengan singkatan: hanya singkatan yang didirikan dengan kuat di bidang yang memenuhi syarat. Kata kunci ini akan digunakan untuk keperluan pengindeksan;

9. JIP hanya menerima pengiriman elektronik (online) melalui website. Oleh karena itu, penulis harus masuk sebelum mengirimkan artikel mereka. Kunjungi: https://journal.scadindependent.org/index.php/jipeuradeun; 
10. Semua catatan harus muncul dalam teks sebagai kutipan (innote). Kutipan biasanya hanya membutuhkan nama belakang penulis, tahun publikasi, dan (kadang-kadang) nomor halaman. Semua karya yang dikutip harus muncul dalam daftar referensi di akhir artikel dan disusun berdasarkan abjad. Dalam hal gaya bibliografi, JIP mengikuti gaya APA edisi ke-6, sebagai berikut:

a. Setiap kata benda dan kata kerja awal dalam judul buku ditulis dengan huruf kapital. Judul buku harus dicetak miring:

- Audi, Robert (2000). Religious Commitment and Secular Reason. New York: Cambridge University Press.

- ZA, T. (2015). Persuit Epistemologi of Islamic Studies (Buku 2 Arah Baru Metodologi Studi Islam). Penerbit Ombak, Yogyakarta

b. Jika rujukannya adalah jurnal, nama jurnal dicetak miring. Selain itu, juga menunjukkan volume, issue, dan halaman. Contoh:

- Dumanig, F.R. (2014). Social Capital and Politeness Strategies in Fostering Ethnic Relations in Malaysia and Philippines. Jurnal IImiah Peuradeun. 2 (3): 23 38;

- Kaylene, P., \& Rosone, T. L. (2016). Multicultural Perspective on the Motivation of Students in Teaching Physical Education. Jurnal I/miah Peuradeun, 4(1), 115-126.

- Untuk lebih lanjut: silahkan anda akses Manual Publikasi American Psychological Association, Edisi 6, ISBN 1-55798-790-4, salinannya dapat dipesan dari: http://www.apa.org/books/4200061.html. 
Detail mengenai gaya referensi ini juga dapat ditemukan di:

\section{http://linguistics.byu.edu/faculty/henrichsenl/apa/ap a01.html;}

11. Jika ada informasi dan penjelasan yang berkaitan dengan klarifikasi lebih lanjut dari isi kutipan naskah anda dapat menggunakan catatan kaki;

12. Naskah yang diterbitkan akan melalui proses penyuntingan tanpa mengubah substansi;

13. Naskah yang masuk ke editor, dikategorikan:

14. Naskah yang diterbitkan atau tidak diterbitkan, akan diinformasikan kepada penulis melalui email dan dapat dilihat langsung di akun JIP Anda;

15. Naskah yang diterbitkan dapat dilihat langsung dalam edisi JIP terbaru secara online;

16. Mulai dari September 2017, JIP tidak lagi memberikan versi cetak kepada penulis. Jika Anda ingin versi cetak, silakan hubungi kami melalui email; info.jip@scadindependent.org. 
How to Get Your Research Published and Then Noticed 


\section{Bibliography}

Abdullah, A., \& Tabrani ZA. (2018). Orientation of Education in Shaping the Intellectual Intelligence of Children. Advanced Science Letters, 24(11), 8200-8204. https://doi.org/10.1166/asl.2018.12523

AR, M., Usman, N., Tabrani ZA, \& Syahril. (2018). Inclusive Education Management in State Primary Schools in Banda Aceh. Advanced Science Letters, 24(11), 8313-8317. https://doi.org/10.1166/asl.2018.12549

Bean, J. C. (2011). Engaging ideas: The professor's guide to integrating writing, critical thinking, and active learning in the classroom. John Wiley \& Sons.

Bem, D. J. (2003). Writing the empirical journal article. In Darley, J. M., Zanna, M. P., \& Roediger III, H. L. (Eds.), The compleat academic: $A$ practical guide for the beginning social scientist (2nd ed., pp.171-201). Washington, DC: American Psychological Association.

Booth, W. G., Colomb, G. G., and Williams, J. M. (2008). The Craft of Research (3rd ed.). Chicago: University Of Chicago Press.

Eggen, P., \& Kauchak, D. (2001). Educational Psychology: Windows on Classrooms. 8th.

Epstein, D., Kenway, J., \& Boden, R. (2005). Writing for Publication. London: Sage Publications.

Hubbuch, S.M. (1996). Writing research papers across the curriculum (4th ed.). Fort Worth, TX: Harcourt Brace College Publishers. 
Idris, S., \& Tabrani ZA. (2017). Realitas Konsep Pendidikan Humanisme dalam Konteks Pendidikan Islam. JURNAL EDUKASI: Jurnal Bimbingan Konseling, 3(1), 96-113. https://doi.org/10.22373/je.v3i1.1420

Idris, S., Tabrani ZA, \& Sulaiman, F. (2018). Critical Education Paradigm in the Perspective of Islamic Education. Advanced Science Letters, 24(11), 8226-8230. https://doi.org/10.1166/asl.2018.12529

Katz, M.J. (2006). From research to manuscript: $A$ guide to scientific writing. Dordrecht, The Netherlands: Springer.

Lang, H. R., \& Evans, D. N. (2006). Models, strategies, and methods for effective teaching. Allyn \& Bacon.

Marin, L. M., \& Halpern, D. F. (2011). Pedagogy for developing critical thinking in adolescents: Explicit instruction produces greatest gains. Thinking Skills and Creativity, 6(1), 1-13.

Patimah, S., \& Tabrani ZA. (2018). Counting Methodology on Educational Return Investment. Advanced Science Letters, 24(10), 7087-7089. https://doi.org/10.1166/asl.2018.12414

Siswanto, R., Sugiono, S., \& Prasojo, L. D. (2018). The Development of Management Model Program of Vocational School Teacher Partnership with Business World and Industry Word (DUDI). Jurnal Ilmiah Peuradeun, 6(3), 365-384.

Tabrani ZA and Masbur. (2016). Islamic Perspectives on the Existence Of Soul and its Influence in Human Learning ( $A$ Philosophical Analysis of the Classical and Modern Learning Theories). Jurnal Edukasi: Jurnal Bimbingan Konseling, 1(2), 99-112. 
Tabrani ZA. (2009). IImu Pendidikan Islam (antara Tradisional dan Modern). Kuala Lumpur: Al-Jenderami Press.

Tabrani ZA. (2011). Dynamics of Political System of Education Indonesia. International Journal of Democracy, 17(2), 99-113.

Tabrani ZA. (2012). Future Life of Islamic Education in Indonesia. International Journal of Democracy, 18(2), 271-284

Tabrani ZA. (2013). Pengantar Metodologi Studi Islam. Banda Aceh: SCAD Independent.

Tabrani ZA. (2014). Islamic Studies dalam Pendekatan Multidisipliner (Suatu Kajian Gradual Menuju Paradigma Global). Jurnal IImiah Peuradeun, 2(2), 211-234.

Tabrani ZA. (2014b). Dasar-Dasar Metodologi Penelitian Kualitatif. Yogyakarta: Darussalam Publishing.

Tabrani ZA. (2015a). Arah Baru Metodologi Studi Islam. Yogyakarta: Penerbit Ombak.

Tabrani ZA. (2015b). Persuit Epistemology of Islamic Studies (Buku 2 Arah Baru Metodologi Studi Islam). Yogyakarta: Penerbit Ombak.

Tabrani ZA. (2015c). Keterkaitan Antara IImu Pengetahuan dan Filsafat (Studi Analisis atas QS. Al-An'am Ayat 125). Jurnal Sintesa, 14(2), 1-14.

Tabrani ZA. (2017). Menggugat Logika Nalar Rasionalisme Aristoteles. Yogyakarta: Mizan.

Tabrani ZA. (2018), Menulis Artikel untuk Jurnal IImiah. Method in Researcgate, Agustus 2018, doi: 10.13140/RG.2.2.31714.38081. 
The Royal Society. (2010). Philosophical Transactions of the Royal Society of London. Retrieved July 25, 2018, from http://rstl.royalsocietypublishing.org/

Tsai, K. C. (2014). A journey to the Qualitative Wonderland: Lessons Learned for Novice Researchers. Jurnal I/miah Peuradeun, 2(3), 39-50.

Usman, N., AR, M., Murziqin, R., \& Tabrani ZA. (2018). The Principal's Managerial Competence in Improving School Performance in Pidie Jaya Regency. Advanced Science Letters, 24(11),

8297-8300. https://doi.org/10.1166/asl.2018.12545

Walidin, W., Idris, S., \& Tabrani ZA. (2015). Metodologi Penelitian Kualitatif \& Grounded Theory. Banda Aceh: FTK Ar-Raniry Press.

Wellington, J. (2003). Getting published: A guide for lecturers and researchers. London: Routledge Falmer.

Young, P. (2006). Writing and presenting in English: The Rosetta stone of science. Oxford: Elsevier.

Ziman, J. (1978). Reliable knowledge: An exploration of the grounds for belief in science. Cambridge: Cambridge University Press. 